



\section{Estimating requirement values for apparent faecal digestible and standardised ileal digestible lysine in broilers by a meta-analysis}

T. Veldkamp, J.W. van Riel, R.A. Dekker, S. Khalaji, V. Khaksar, H. Hashemipour, M.M. van Krimpen, M.C. Blok 
Veldkamp, T., J.W. van Riel, R.A. Dekker, S. Khalaji, V. Khaksar, H. Hashemipour, M.M. van Krimpen, M.C. Blok, 2016. Estimating requirement values for apparent faecal digestible and standardised ileal digestible lysine in broilers by a meta-analysis approach. Wageningen UR (University \& Research centre) Livestock Research, Livestock Research Report 965.

(C) 2016 Wageningen UR Livestock Research, P.O. Box 338, $6700 \mathrm{AH}$ Wageningen, The Netherlands, T +31 (0) 3174839 53, E info.livestockresearch@wur.nl, www.wageningenUR.nl/en/livestockresearch. Livestock Research is part of Wageningen UR (University \& Research centre).

All rights reserved. No part of this publication may be reproduced and/or made public, whether by print, photocopy, microfilm or any other means, without the prior permission of the publisher or author.

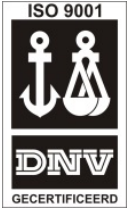

The ISO 9001 certification by DNV underscores our quality level. All our research commissions are in line with the Terms and Conditions of the Animal Sciences Group. These are filed with the District Court of Zwolle.

Livestock Research Report 965 - http://dx.doi.org/10.18174/388690 


\section{Table of contents}

$\begin{array}{ll}\text { Preface } & 5\end{array}$

$\begin{array}{ll}\text { Summary } & 6\end{array}$

\begin{tabular}{l|lr}
1 & Introduction & 8
\end{tabular}

$2 \quad$ Material and Methods $\quad 10$

$\begin{array}{lll}2.1 & \text { Database } & 10\end{array}$

2.2 Criteria for inclusion of papers into the database 10

$\begin{array}{lll}2.3 & \text { Calculations } & 11\end{array}$

2.4 Statistical analysis $\quad 12$

2.4.1 Regression analysis per experiment $\quad 12$

2.4.2 Overall regression (Regression analysis over experiments) 12

$\begin{array}{ll}\text { Lysine requirement values } & 14\end{array}$

$\begin{array}{lll}3.1 & \text { Lysine background information on meta-analysis } & 14\end{array}$

3.1.1 Study details individual studies $\quad 14$

3.1.2 Results of curve fitting and lysine requirements for individual studies $\quad 15$

3.1.3 Results of overall curve fitting and lysine requirements as a function of age16

$\begin{array}{lll}3.2 & \text { Lysine requirement values } & 16\end{array}$

3.2.1 Requirement of AFD lysine expressed on dietary content for body weight gain

3.2.2 Requirement of AFD lysine expressed on dietary content for feed conversion ratio

3.2.3 Requirement of SID lysine expressed on dietary content for body weight gain

3.2.4 Requirement of SID lysine expressed on dietary content for feed conversion ratio

3.3 Requirement values of lysine on AFD and SID basis, expressed as content in the diet, at different ages for BWG and FCR

Acknowledgement

\section{Appendices 23}

Appendix 1 List of references which have not been included in the database with reason

Appendix 2 The determined responses of body weight gain ( $g / d$ ) as a function of the AFD and SI D lysine content for each individual experiment ( $\% \mathrm{CV}=$ coefficient of variation; in brackets)

Appendix 3 The determined responses of feed conversion ratio as a function of the AFD and SI D lysine content for each individual experiment ( $\% \mathrm{CV}=$ coefficient of variation; in brackets)

Appendix 4 Experiments for which the requirement on the AFD and SI D lysine concentration for BWG was estimated according to equation 2 and that also met the criteria for the overall regression to estimate the relationship of the AFD and SID lysine requirement for BWG with age

Appendix 5 Experiments for which the requirement on the AFD and SI D Iysine concentration for FCR was estimated according to equation 2 and 
that also met the criteria for the overall regression to estimate the relationship of the AFD and SID lysine requirement for FCR with age

Appendix 6 References omitted in the overall regression of BWG response to AFD and SI D lysine content

Appendix 7 References omitted in the overall regression of FCR response to AFD and SI D lysine content 


\section{Preface}

Diet composition, e.g. concentrations of energy, protein, vitamins and minerals, largely influence the zootechnical performance of poultry. Nowadays, protein requirements are more precisely described in terms of apparent faecal digestible amino acid (AFD) or standardised ileal digestible amino acid (SID) requirement values and amino acid profiles expressing the requirement of each amino acid relative to lysine. Appropriate requirement values for amino acids (AA) in poultry diets are essential for optimizing poultry production and profit of the poultry chain.

CVB, formerly part of the Dutch Product Board Animal Feed (PDV) and now part of the Federatie Nederlandse Diervoedingsketen (FND; Federation Dutch Animal Feed Chain), is responsible for recommending the Dutch poultry chain on AA requirements for various poultry species. The latest public review of AA requirements in poultry in the Netherlands was presented two decades ago (Schutte et al., 1996). As a consequence of several recent developments such as change in genetic predisposition for growth, the increasing trend of formulating low-protein diets and the increasing availability of free AA for supplementation in broilers diets, it was recommended that requirement values for AA in broiler diets should be updated. The present study was subsidized by the (former) Product Board Animal Feed and the (former) Product Board Poultry and Eggs. 


\section{Summary}

Requirement values for apparent faecal digestible and standardised ileal digestible lysine of broilers at different ages were estimated by a meta-analysis approach. This study was part of a project to estimate the apparent faecal (AFD) and standardized ileal digestible (SID) amino acid requirement values of the first limiting amino acids in both broilers and laying hens.

Peer reviewed papers were selected, describing experimental results of dose response studies in which the effect of graded levels of free amino acids supplemented to a basal diet on body weight gain and feed conversion ratio in broilers was studied. The papers searched for were published during the period 1994 2012. Subsequently, a stepwise process was applied for the selection of the research data to be used in the meta-analysis. In total 11 criteria were set. Two of these criteria are: at least three graded levels of supplementation of the amino acid of interest to the same basal diet; maximal supplementation of the amino acid of interest was at least $10 \%$ higher compared to the concentration of the amino acid of interest in the basal (non-supplemented) diet. Feed ingredient composition of the experimental diets should be present in each paper; this information was included in a separate database and nutrient composition of the experimental diets was recalculated by using data on the nutritional composition of the individual feed ingredients according to the CVB Feed Table (2007). When the determined level of the amino acid of interest (and - when presented - of other amino acids) on an AFD basis was published, this information was used. In case this information was not presented, the level of the amino acid of interest (and of other amino acids) was calculated by using either the total amino acid levels in the basal diets as analysed by the authors or as calculated by using the CVB Feed Table (2007) in combination with the digestibility on an AFD basis as published by CVB (CVB Table, 2007) In addition, the concentrations of standardized ileal digestible (SID) amino acids in the diets of each study were also calculated using the digestibility on an SID basis as tabulated by CVB (Dekker and Blok, in press) and were included in the database. These (calculated) dietary concentration of AFD and SID amino acids were used in the present study for the regression analyses to derive requirement values for AFD and SID amino acids in broilers.

The responses of body weight gain (BWG) and feed conversion ratio (FCR) to supplementation of the free amino acid of interest to a basal diet were analysed for each individual experiment included in the database by regression analysis. Mean data for BWG and FCR per experimental group as provided in the original paper were used as response parameters. Response of BWG and FCR to supplementation of the free amino acid of interest was determined by use of an exponential model. For each individual experiment the estimated requirement (Req) for the amino acid of interest was calculated as the amino acid concentration at which $95 \%$ of the response (BWG and FCR) between intercept and asymptotic value was reached. Data of studies that could not be fitted with the exponential model were excluded from further evaluation. Also studies, where the estimated requirement value was over $110 \%$ of the maximum concentration of the amino acid of interest in the diet with the highest supplementation level, were excluded from further evaluation. Studies in which a non-test amino acid might have been colimiting ( $<90 \%$ of CVB 1996) at higher supplementation levels of the amino acid of interest were also excluded from the dataset. After estimation and evaluation of the amino acid requirement values for the individual studies, an overall regression model was used to fit the requirement values of the amino acid of interest on an AFD and SID basis for BWG and FCR as a function of age of the broilers. For this purpose the mean age of broilers in each experiment was calculated as (age at start of the experimental period + age at the end of the experimental period) $/ 2$.

In total, 26 studies each containing one or more experiments, were judged. In total, 28 experiments from 11 papers that met the criteria were included into the database. Requirement values of AFD and SID lysine concentrations in the diet were estimated at different ages. A summary is presented in the Table. 


\begin{tabular}{|c|c|c|c|c|c|}
\hline \multirow[t]{2}{*}{ Day } & \multirow{2}{*}{$\begin{array}{c}\text { AFD lysine ( } \% \text { in diet) } \\
\text { CVB (2007) }\end{array}$} & \multicolumn{2}{|c|}{ AFD lysine ( $\%$ in diet) } & \multicolumn{2}{|c|}{ SI D Iysine ( $\%$ in diet) } \\
\hline & & $\begin{array}{c}\text { Body weight } \\
\text { gain }\end{array}$ & $\begin{array}{c}\text { Feed conversion } \\
\text { ratio }\end{array}$ & $\begin{array}{c}\text { Body weight } \\
\text { gain }\end{array}$ & $\begin{array}{c}\text { Feed conversion } \\
\text { ratio }\end{array}$ \\
\hline 7 & 1.05 & 1.19 & 1.26 & 1.20 & 1.28 \\
\hline 14 & 1.02 & 1.11 & 1.19 & 1.13 & 1.21 \\
\hline 21 & 1.02 & 1.07 & 1.15 & 1.09 & 1.17 \\
\hline 28 & 0.99 & 1.04 & 1.12 & 1.06 & 1.15 \\
\hline 35 & 0.99 & 1.02 & 1.10 & 1.04 & 1.12 \\
\hline 42 & 0.99 & 1.00 & 1.08 & 1.02 & 1.11 \\
\hline
\end{tabular}

Estimated AFD and SID lysine requirements for BWG are lower than for FCR. Until four weeks of age the AFD and SID lysine requirement for BWG are significantly higher than the CVB (2007) recommendations for AFD lysine requirement. AFD and SID lysine requirement for FCR are over the entire period significantly higher than the CVB (2007) recommendations for AFD lysine requirement. 


\section{$1 \quad$ Introduction}

Diet composition, e.g. concentrations of energy, protein, vitamins and minerals, largely influence the zootechnical performance of poultry. Nowadays, protein requirements are more precisely described in terms of digestible amino acid requirements and amino acid profiles expressing the requirement of each amino acid relative to lysine. Appropriate digestible amino acid requirements in poultry diets are essential for optimizing poultry production and profit of the poultry chain.

CVB, formerly part of the Dutch Product Board Animal Feed (PDV) and now part of the Federatie Nederlandse Diervoedingsketen (FND; Federation Dutch Animal Feed Chain), is responsible for advising the Dutch feed industry on nutrient requirements for various poultry species. The latest public review on amino acid requirements in poultry in the Netherlands, however, was conducted two decades ago (CVB, 1996). The requirement values of amino acids (CVB, 1996) were expressed on an apparent faecal digestible (AFD) basis. As a consequence of several recent developments, it was recommended that amino acid requirements should be updated:

- The genetic predisposition for body weight gain of broilers has increased substantially during the last decades;

- $\quad$ The increasing trend of formulating low-protein diets;

- The increasing availability of free amino acids for diet supplementation;

- $\quad$ Different feeding strategies are developed to improve animal welfare and (intestinal) health.

Nutrient requirements have been determined in many experiments. A general method for integrating quantitative knowledge from multiple experiments has been proposed and is referred to as meta-analysis (St-Pierre, 2001). The technique is based on collecting data from multiple published studies that fulfil a number of criteria and formulating a statistical model that best explains the observations (van Houwelingen et al., 2002). Moreover, the meta-analytical approach is highly suited for establishing requirements values because it focuses on estimating on a population level from multiple studies, while accounting for the heterogeneity between studies. The statistical model used in meta-analytical studies should be based on a hierarchical or a mixed model, which has at least two stages (van Houwelingen et al., 2002). The first-stage hierarchy models the within-study variability as a function of the primary covariate (e.g., Lys content). The second-stage hierarchy models the between-study variability through individual random effects and study-related covariates (e.g. strain, gender, year of publication etc.), identifying systematic trends among studies.

Meta-analysis, which combines the results from various experiments at the same time, has more power to detect small differences. For estimating amino acid requirement values by use of a meta-analysis approach, formulating criteria for inclusion or exclusion of studies is very important. The main requirement for a proper meta-analysis is a well-executed systematic review. Therefore in the current work, key journals were searched and reference lists of papers were checked carefully.

The current requirement values for amino acids in broilers (CVB, 1996) are expressed on an apparent faecal digestible (AFD) basis. For the present study it was recommended by CVB to estimate requirement values for amino acids in broilers on a standardized ileal digestible basis. According to Lemme et al. (2004) and Adedokun et al. (2008) standardised ileal amino acid digestibility (SID) coefficients are corrected for the contribution of amino acids of basal endogenous origin to the total ileal digesta pool. Changing the system of expressing amino acid requirement values based on AFD into SID amino acid concentration of dietary ingredients affect the amino acid requirement values of broilers. It is important that amino acid requirement values and the dietary supply of amino acids are expressed identically. 
The present study was part of a project conducted to estimate requirement values for the first limiting apparent faecal digestible (AFD) and standardized ileal digestible (SID) amino acids in broilers and laying hens at different ages using a meta-analysis approach. In this report the requirement values for lysine in broilers are described. 


\section{$2 \quad$ Material and Methods}

\section{$2.1 \quad$ Database}

Peer reviewed papers were selected, describing experimental results of dose response studies in which the effect of graded levels of free amino acids of interest supplemented to a basal diet on body weight gain (BWG) and feed conversion ratio (FCR) in broilers was studied. The papers were searched by using the key words 'broiler' and 'name of relevant amino acid' in the electronic database 'Web of Science'. The papers searched for were published during the period 1994 - 2012. Search results in which the requirement of lysine was studied were found in Asian-Australian Journal of Animal Science, Brazilian J ournal of Veterinary and Animal Science, British Poultry Science, Italian J ournal of Animal Science, Journal of Applied Poultry Research, Journal of Animal and Veterinary Advances, Poultry Science, Revista Brasileira de Zootecnia and Statistics in Medicine. A stepwise process was applied for the selection of research data to be used.

\subsection{Criteria for inclusion of papers into the database}

The studies were reviewed according to the following inclusion criteria:

1. The experimental procedure should be adequately provided, meaning a clear description of the experimental units, the number of broilers per unit, the age of the broilers and the duration of the experiment;

2. Provision of information on the broilers used (strain, age);

3. Provision of information on the (metabolizable) energy content of the diets (for adult cockerels);

4. Provision of information on how amino acid levels in the basal diet(s) in the paper are expressed (total, faecal, ileal, on an apparent or standardized basis);

5. Only dose response studies were included in which besides a basal level of the amino acid of interest at least three graded levels of supplementation of the amino acid of interest to the same basal diet were tested;

6. Only dose response studies were included in which the maximal supplementation of the amino acid of interest was at least $10 \%$ higher compared to the concentration of the amino acid of interest in the basal (non-supplemented) diet;

7. With the exception of the concentration of the amino acid of interest (that should be - far - below the CVB requirement), the concentration of the following amino acids in the basal diet should be at least $90 \%$ of the CVB (1996) requirement (on AFD basis) for methionine+cysteine, threonine and tryptophan. For isoleucine, arginine and valine the concentration in the basal diet should be at least $85 \%$ of the CVB (1996) requirement (on AFD basis), because the requirements of these amino acids were documented less accurately;

8. Experimental diets should be adequately described in terms of ingredient composition and should contain analysed or calculated contents for at least crude protein and essential amino acids;

9. Feed intake levels of experimental groups (receiving the diets with supplemented free amino acid) within the same experiment should be less than $150 \%$ relative to the feed intake level of the group fed the basal, non-supplemented basal diet;

10. Provision of data on feed intake, BWG and FCR in dose response studies with broilers in which the effects of increasing levels of the dietary amino acid of interest was evaluated by supplementing a basal diet with different levels of the free amino acid of interest;

11. Supplementation of the free amino acid of interest to the basal diet should have a statistical significant effect on BWG and/or FCR according to the original author. 
Information of the papers that met these inclusion criteria was included in a database. Besides the information on the inclusion criteria as mentioned above, additional information from the study (if available) was added also to the database (e.g. strain, sex, etc.). Further, the amino acid requirement value as derived by the original author(s) of the study was included in the database as well and also the statistical method to estimate the amino acid requirement under study was included. Studies not meeting the inclusion criteria as mentioned above, were excluded from the database and the reason for exclusion was recorded (See Appendix 1).

\subsection{Calculations}

Feed ingredients in the basal diet composition used in each experiment of studies that met the criteria in Paragraph 2.2 were included in a separate database. Subsequently, nutrient composition of these experimental diets was recalculated by using data on the nutritional composition of the individual feed ingredients according to the CVB Feed Table (2007). Regarding the levels of digestible amino acids the following procedure was used:

a. When the paper presents the level of lysine in the basal diets expressed on a (apparent faecal) digestible basis, it was decided to use this figure. As far as the levels of one or more other amino acids (see criterion 7 for the other amino acids that were considered to be relevant), were also expressed on this basis, this information was used in the further processing of the study. For those amino acids for which this information was lacking, the level of digestible amino acid was calculated according to option b. or c.;

b. When no information was presented in the paper on the level of (apparent) faecal digestible lysine and/or other amino acids, the next option was to use the total level of lysine and/or of the other amino acids as analysed in the basal diets. Using the faecal amino acid digestibility of the feed ingredients in the CVB Feed Table (2007), the faecal digestibility of the amino acids in the basal diet and, subsequently, the level of apparent faecal digestible amino acids was calculated;

c. When no information as described in the options a. and b. was available, the total levels of the amino acids needed were calculated using the ingredient composition of the experimental diets (see criterion 8) as presented in the paper. In these cases the starting point was the ingredient composition (Weende analysis, ME value and amino acid pattern) as published in the CVB Feed Table 2007. To reproduce satisfactory the level of crude protein and - when given - the metabolizable energy level as given in the paper, in a number of cases (slight) adjustment of the protein level and - as a consequence - the amino acid levels of - preferably - the protein rich ingredients was necessary. Subsequently, the digestible amino acid levels on an AFD basis were calculated using the digestibility in the CVB Feed Table (2007).

In addition, the concentrations of standardized ileal digestible (SID) amino acids in the basal diets of each study were also calculated using option b. or c. and were included in the database. The standardized ileal amino acid digestibility coefficients of feed ingredients required for the calculation of SID amino acid contents were derived from Dekker and Blok (in press).

The supplemented free amino acids were considered to be $100 \%$ digestible, both on an AFD and SID basis.

The calculated dietary concentrations of AFD and of SID lysine were used in the present study for the regression analyses to derive requirement values for lysine on an AFD and SID basis for Body Weight Gain (BWG) and Feed Conversion Ratio (FCR) in broilers. 


\subsection{Statistical analysis}

\subsubsection{Regression analysis per experiment}

The responses of BWG and FCR to supplementation of the free amino acid of interest to a basal diet were analysed by regression analysis. Mean data for BWG and FCR per experimental group as provided in the original paper were used as response parameters. The response of BWG and FCR to supplementation of free amino acid of interest was determined by use of an exponential model as is described by the following mathematical equation:

$Y_{i j}=a_{i}+b_{i} *\left(1-e^{(-C i * d x)}\right)+\underline{\varepsilon i j}(\mathbf{1})$

Where: $Y_{i j}=$ response value of BWG or FCR for experiment $\mathrm{i}$ and treatment $\mathrm{j}$;

$a_{i}=$ estimated basal level (for $d x=0$ ) of the amino acid of interest for experiment $i$;

$b_{i} \quad=$ difference between basal level and estimated asymptotic level for BWG and FCR response for experiment i;

$\mathrm{C}_{\mathrm{i}} \quad=$ rate parameter (for speed of curving) for experiment $\mathrm{i}$;

$\mathrm{dx}=$ difference in amino acid concentration of interest (AFD or SID based) compared to basal (non-supplemented diet) in experiment $\mathrm{i} ;\left(\mathrm{X}_{\mathrm{i}}-\mathrm{MIN}\left(\mathrm{X}_{\mathrm{i}}\right)\right) ; \mathrm{X}_{\mathrm{i}}=$ amino acid concentration of interest in experimental diets, $\mathrm{MIN}\left(\mathrm{X}_{\mathrm{i}}\right)=$ amino acid concentration of interest in basal (non-supplemented) diet;

$\varepsilon i j=$ error $\mathrm{ij}$.

For each individual experiment the estimated requirement (Req) for the amino acid of interest was calculated as the amino acid concentration where $95 \%$ of the response (BWG and FCR) between intercept and asymptotic value was reached. The estimated amino acid requirement was calculated by the following mathematical equation:

$\operatorname{Req}_{i}=\frac{\ln (0.05)}{-C i}+\operatorname{MIN}(\mathrm{Xi})(\mathbf{2})$

Where: $\operatorname{Req}_{\mathrm{i}}=$ Estimated amino acid requirement $(\%)$ of the individual experiment $\mathrm{i}$;

$\operatorname{Ln}(0.05)={ }^{e} \log (0.05)$;

$\mathrm{C}_{\mathrm{i}} \quad=$ rate parameter (for speed of curving) for experiment $\mathrm{i}$;

$\operatorname{MIN}\left(X_{i}\right)=$ amino acid $(\%)$ in basal (non-supplemented) diet.

\subsubsection{Overall regression (Regression analysis over experiments)}

After estimation of the amino acid requirement values for individual studies by using the exponential model according to equation 2, the amino acid requirement as a function of age was studied.

However, before doing this the results from the previous step were evaluated according to the following criteria:

- Mean age of the animals.

The mean age of broilers was determined in each experiment as (days of age at start of the experimental period + days of age at the end of the experimental period)/2. Experiments in which the mean age was $>42$ days were excluded from the database for the overall regression.

- Calculated requirement (as the AFD or SID amino acid level at which $95 \%$ of the plateau level was reached) was compared to the highest dietary amino acid level in the experiment.

When the calculated requirement was $>110 \%$ of the amino acid level in the treatment with the highest supplemented amino acid level, the study was excluded from the database for the overall regression

- Lack of fit.

Studies in which no requirement could be estimated according to equation 2 were excluded from the database for the overall regression.

- Co-limitation of other amino acids 
In the first review (see paragraph 2.2, criterion 7) only studies were included in the database if, besides the concentration of the amino acid of interest, the concentration of several other essential amino acids in the basal diet was at least $90 \%$ or $85 \%$ (depending on the amino acid) of the requirement (on AFD basis) according to CVB (1996). In this second review it was evaluated if the ratios of these amino acids relative to the amino acid of interest on an AFD basis were at least 0.90 of the ratio of the requirement of the same amino acids on an AFD basis according to CVB (1996). In formula:

(level non test amino acid $X$ basal diet in study $\mathrm{y}_{\mathrm{i}} /\left(\right.$ calculated requirement test amino acid in study $\left.\mathrm{y}_{\mathrm{i}}\right) \geq$ $0.90 *$ (requirement non test amino acid X, CVB 1996)/( requirement test amino acid, CVB 1996).

The regression model for the requirement of SID amino acid content and AFD amino acid content is described by the following mathematical equation:

$\operatorname{Req}_{i}=ß_{0}+ß_{1} * \ln \left(A_{g e}\right)+\underline{\varepsilon i}(3)$

Where: $\operatorname{Req}_{\mathrm{i}} \quad=$ amino acid requirement (content (\% in diet))

$B_{0}=$ estimated amino acid requirement at hatch

$B_{1} \quad=$ estimated linear effect of $\ln ($ Age $)$

$\ln \left(\mathrm{Age}_{\mathrm{i}}\right)=\mathrm{e} \log ($ Age $\mathrm{i})$

Age $\quad=$ average age of broilers in experiment $(\mathrm{d})$

Selection of candidate models with more factors included such as strain, gender, year, length of the experimental period, was not possible because of the restricted number of experiments that were accepted for overall regression analysis. 


\section{Lysine requirement values}

\subsection{Lysine background information on meta-analysis}

\subsubsection{Study details individual studies}

In total, 26 studies each containing one or more experiments, were judged. Table 1 provides an overview of the 28 experiments from 11 papers that met the criteria described in Paragraph 2.2 for inclusion into the database. The procedure used to calculate the level of apparent faecal digestible lysine (see Par. 2.3) is also mentioned. The number of lysine supplementation levels per experiment ranged from 4 to 10 . The data in the database covered various age periods of birds. In 15 experiments males were used, in 11 experiments females were used and in 2 experiments broilers were as hatched (mixed). Different strains were used in the experiments.

Papers that were not included in the database because studies did not meet the inclusion criteria are mentioned in Appendix 1. 


\section{Table 1}

List of references that met the inclusion criteria for further evaluation of the lysine requirement of broilers in the present study.

\begin{tabular}{|c|c|c|c|c|c|c|}
\hline $\begin{array}{l}\text { Experiment } \\
\text { number }\end{array}$ & Reference & $\begin{array}{l}\text { Nr. of } \\
\text { dose } \\
\text { levels }\end{array}$ & $\begin{array}{l}\text { Range of } \\
\text { AFD Lys } \\
\text { content } \\
(\mathrm{g} / \mathrm{kg})\end{array}$ & $\begin{array}{l}\text { Age of } \\
\text { broilers } \\
\text { (d) }\end{array}$ & Gender & Strain \\
\hline $11^{\text {a) }}$ & Mahdavi et al. (2012) & 6 & 7.7-11.2 & $35-49$ & male & - \\
\hline $12^{\text {a) }}$ & Mahdavi et al. (2012) & 6 & $7.7-11.2$ & $35-49$ & female & - \\
\hline $21^{\text {a) }}$ & Garcia et al. (2006) & 5 & $7.0-11.0$ & $7-21$ & male & Cobb \\
\hline $22^{\text {a) }}$ & Garcia et al. (2006) & 4 & $7.0-10.0$ & $7-21$ & male & Cobb \\
\hline $23^{\text {a) }}$ & Garcia et al. (2006) & 5 & $7.0-11.0$ & $7-21$ & female & Cobb \\
\hline $24^{\text {a) }}$ & Garcia et al. (2006) & 4 & $7.0-10.0$ & $7-21$ & female & Cobb \\
\hline $25^{\text {a) }}$ & Garcia et al. (2006) & 5 & $8.0-11.2$ & $7-21$ & male & Cobb \\
\hline $26^{\text {a) }}$ & Garcia et al. (2006) & 5 & $8.0-11.2$ & $7-21$ & male & Cobb \\
\hline $27^{\text {a) }}$ & Garcia et al. (2006) & 5 & $8.0-11.2$ & $7-21$ & female & Cobb \\
\hline $28^{\text {a) }}$ & Garcia et al. (2006) & 5 & $8.0-11.2$ & $7-21$ & female & Cobb \\
\hline $31^{\text {a) }}$ & Dozier et al. (2009) & 6 & $9.0-12.5$ & $14-28$ & male & Ross \\
\hline $41^{\text {a) }}$ & Dozier et al. (2009) & 9 & $8.5-12.5$ & $14-28$ & male & Ross \\
\hline $42^{\text {a) }}$ & Dozier et al. (2009) & 9 & $8.5-12.5$ & $14-28$ & female & Ross \\
\hline $51^{\text {a) }}$ & Dozier and Payne exp. 1 (2012) & 7 & $9.2-13.9$ & 7-15 & female & Ross \\
\hline $52^{\text {a) }}$ & Dozier and Payne exp. 2 (2012) & 7 & $9.1-14.0$ & $7-15$ & female & HubbardxCobb \\
\hline $53^{\text {a) }}$ & Dozier and Payne exp. 1 (2012) & 7 & $9.2-13.9$ & $1-7$ & female & Ross \\
\hline $54^{\text {a) }}$ & Dozier and Payne exp. 2 (2012) & 7 & $9.1-14.0$ & $1-7$ & female & HubbardxCobb \\
\hline $81^{c)}$ & Mehri et al. (2010) & 6 & $6.2-12.2$ & $15-28$ & mixed & Ross \\
\hline $111^{\text {a) }}$ & Aftab et al. (2007) exp. 1 & 5 & $7.2-9.7$ & $4-21$ & mixed & Hubbard \\
\hline $121^{b)}$ & Fatufe et al. (2004) & 10 & $3.1-15.3$ & $8-21$ & male & Ross \\
\hline $131^{\text {a) }}$ & Berri et al. (2008) & 4 & $8.3-11.3$ & $21-42$ & male & Ross \\
\hline $132^{\text {a) }}$ & Berri et al. (2008) & 4 & $8.3-11.3$ & $21-42$ & male & Ross \\
\hline $141^{\text {a) }}$ & Dozier et al. (2010) & 9 & $6.4-12.0$ & $28-42$ & male & Ross \\
\hline $142^{\text {a) }}$ & Dozier et al. (2010) & 9 & $6.4-12.0$ & $28-42$ & male & Cobb \\
\hline $151^{\text {a) }}$ & Mack et al (1999) & 6 & $6.6-11.1$ & $20-40$ & male & Ross \\
\hline $152^{\text {a) }}$ & Mack et al (1999) & 6 & $6.6-11.1$ & $20-40$ & male & ISA \\
\hline $210^{\text {a) }}$ & Garcia et al. (2006) & 5 & $8.9-12.1$ & $7-21$ & male & Cobb \\
\hline $212^{\text {a) }}$ & Garcia et al. (2006) & 5 & $8.9-12.1$ & $7-21$ & female & Cobb \\
\hline
\end{tabular}

a) Digestible Lys level (on AFD basis) in basal diet analysed by authors and used in present study.

b) Total Lys level in basal diet analysed by authors and used in present study; calculation of digestible Lys level (on AFD basis) in basal diet was done by using these data in combination with the AFD coefficients in the CVB Feed Table (2007).

c) Total Lys level calculated using the ingredient composition as published and the amino acid profile of CVB Feed Table (2007); calculation of digestible Lys level (on AFD basis) was done as described in ${ }^{\text {b). }}$

\subsubsection{Results of curve fitting and lysine requirements for individual studies}

In general, the response of BWG and FCR to AFD and SID lysine content in the experimental diet showed an exponential relationship, when using as input the mean data for BWG and FCR per experimental group as provided in the original paper. The response of BWG and FCR to graded supplementation levels of dietary lysine was determined for all individual experiments according to the exponential model (1) described in paragraph 2.4.1.

The requirement for AFD and SID lysine was determined for each study and defined as the dietary lysine concentration at which $95 \%$ of the response (difference between performance at no additional lysine 
supplementation and the performance at the asymptotic value) was met according to equation (2) in the paragraph 2.4.1.

The results of fitting the individual studies according to equation(2) in the paragraph 2.4.1, together with details of the study and estimated AFD lysine requirement and SID lysine requirement for BWG and FCR are presented in Appendix 2 and 3, respectively. In these Appendices only the results of studies are presented that also met the criteria for inclusion for the overall analysis in paragraph 2.4.2.

\subsubsection{Results of overall curve fitting and lysine requirements as a function of age}

For estimating the AFD and SID lysine requirement as a function of age, an overall regression analysis was conducted on AFD and SID lysine requirement values derived from the individual experiments and the mean age in these experiments according to the general model (3) described in paragraph 2.4.2. An overview of experiments that were included in the overall regression analysis of the experiments is presented in Appendix 4 and 5. Details of the individual experiments and estimated AFD lysine requirement and SID lysine requirement for BWG and FCR are presented in these appendixes as well. Some studies had to be excluded from the overall fitting for both BWG and FCR because of co-limitation of other amino acids or lack of fit (see Appendix 6 and 7).

The results of the overall fitting are presented Paragraph 3.2 (figures $1-4$ ) and in Paragraph 3.3 (Table 3)

\subsection{Lysine requirement values}

In paragraph 3.2.1 up to paragraph 3.2.4 the results of the overall regression analysis on requirement values derived from individual experiments are presented in graphs. Lysine requirement values in these paragraphs are expressed on AFD or SID lysine content in the diet and are expressed for BWG as well as FCR.

\subsubsection{Requirement of AFD lysine expressed on dietary content for body weight gain}

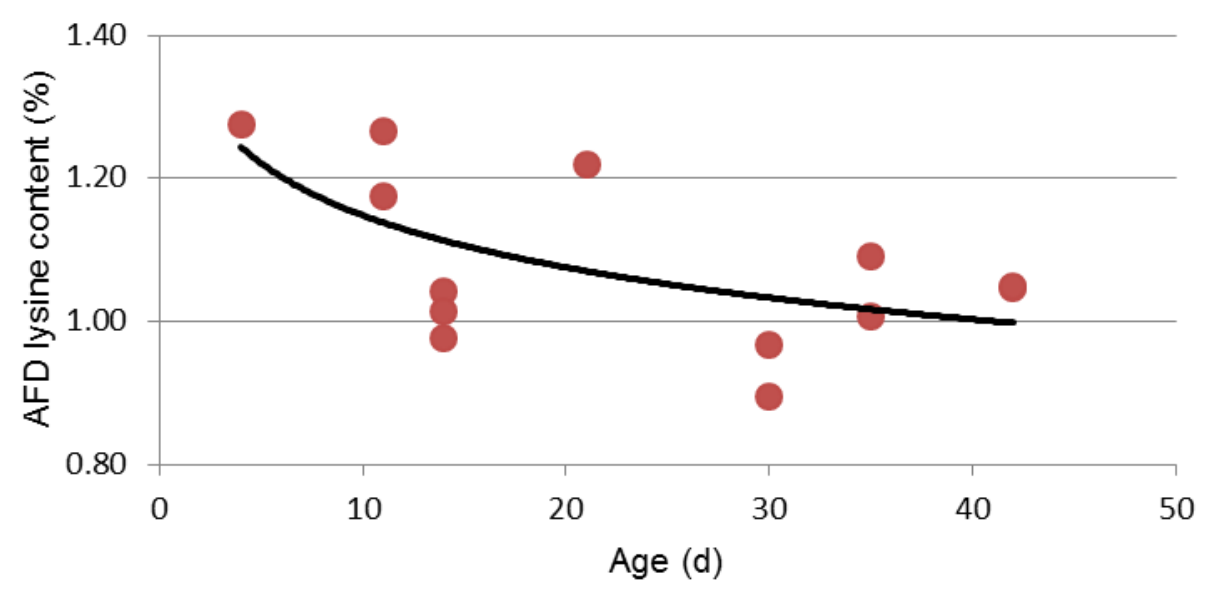

Figure 1 Requirement of AFD lysine content (\% in diet) for body weight gain at different ages (based on Exp.no. 11, 12, 22, 28, 212, 41, 51, 52, 54, 141, 142, 151, 152). The point at day 42 covers the results of two experiments.

The fitted requirement of AFD lysine, expressed as a percentage of diet, for BWG was based on thirteen experiments. 


\subsubsection{Requirement of AFD lysine expressed on dietary content for feed conversion ratio}

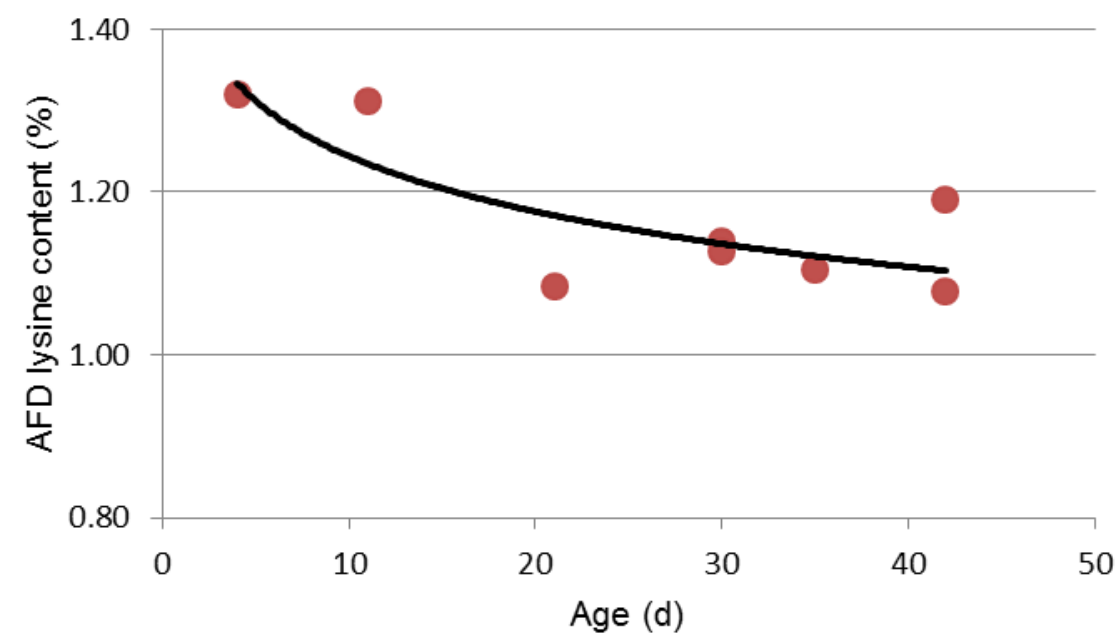

Figure 2 Requirement of AFD lysine content (\% in diet) for feed conversion ratio at different ages (based on Exp.no.11, 12, 42, 52, 54, 142, 151 and 152). The point at day 30 covers the results of two experiments.

The fitted requirement of AFD lysine content expressed as a percentage of diet for FCR at different ages was based on eight experiments.

\subsubsection{Requirement of SID lysine expressed on dietary content for body weight gain}

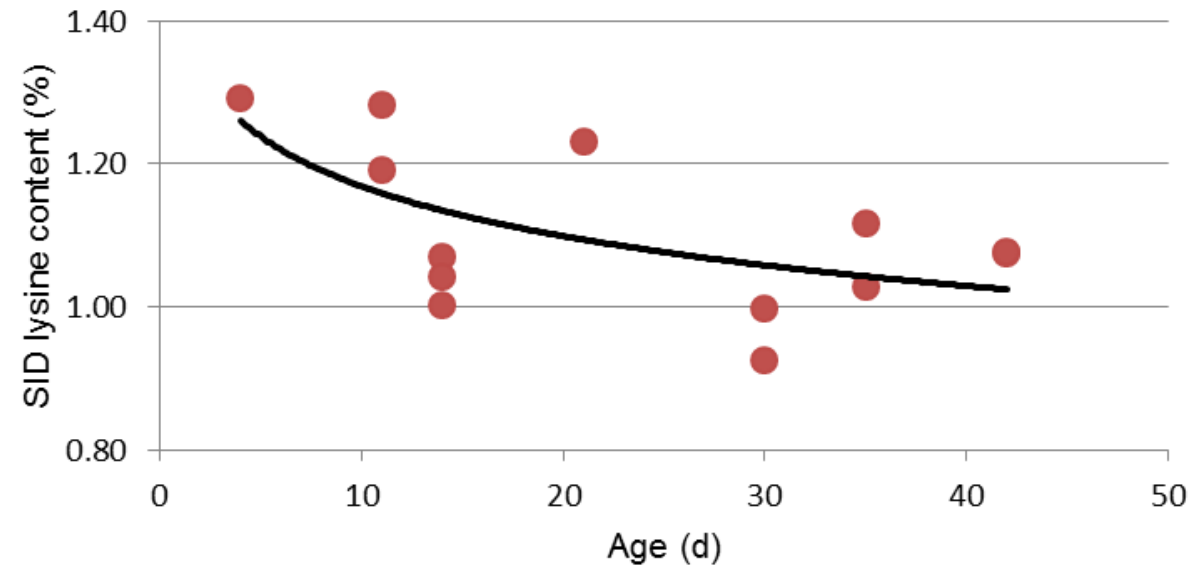

Figure 3 Requirement of SID lysine content (\% in diet) for body weight gain at different ages (based on Exp.no. 11, 12, 22, 28, 212, 41, 51, 52, 54, 141, 142, 151 and 152). The points at day 42 covers the results of two experiments.

The fitted requirement of SID lysine content, expressed as a percentage of diet for BWG at different ages was based on thirteen experiments. 
3.2.4 Requirement of SID lysine expressed on dietary content for feed conversion ratio

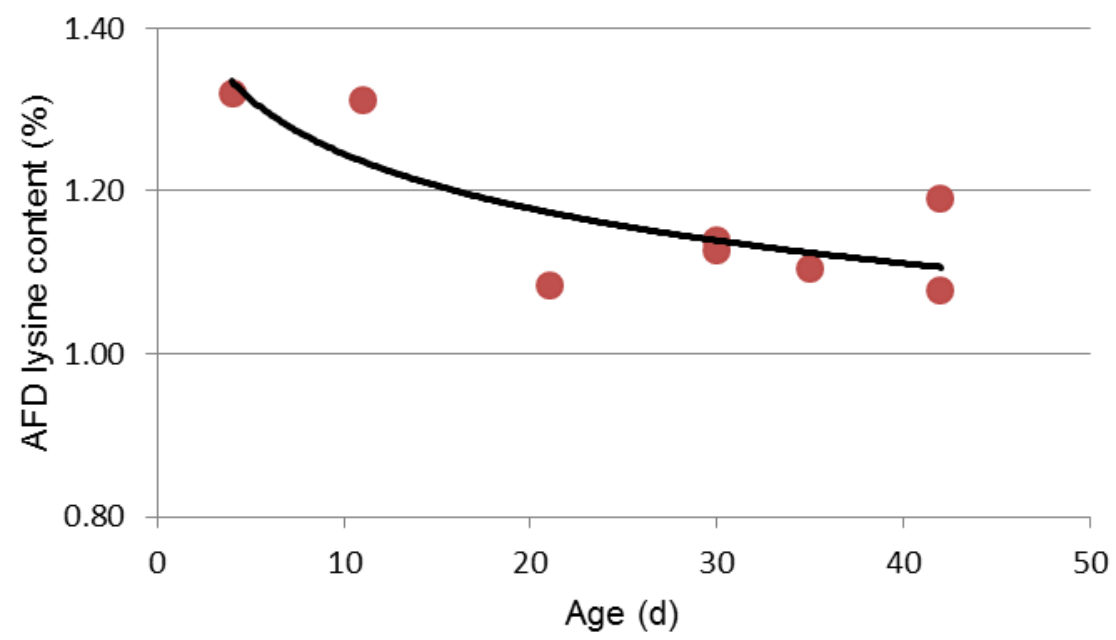

Figure 4 Requirement of SID lysine content (\% in diet) for feed conversion ratio at different ages (based on Exp.no 11, 12, 42, 52, 54, 142, 151 and 152). The point at day 30 covers the results of two experiments.

The fitted requirement of SID lysine content for FCR expressed as a percentage of diet at different ages was based on eight experiments.

\subsection{Requirement values of Iysine on AFD and SID basis, expressed as content in the diet, at different ages for BWG and FCR}

The overall regression analyses for the requirement values of AFD and SID lysine content for BWG and FCR as a function of age, resulted in the formulas presented in Table 2. In all cases, lysine requirement decreased with age significantly.

\section{Table 2}

Mathematical description of the AFD and SID lysine requirement, expressed as content in the diet, for BWG and FCR as a function of age based on the overall regression analysis (standard errors in brackets)

\begin{tabular}{lll} 
& Overall regression analysis ${ }^{1}$ & P-value for age \\
AFD / BWG & $Y=1.390(0.1259)-0.1050(0.04145) * L N($ age $)$ & 0.028 \\
\hline AFD/FCR & $Y=1.461(0.0867)-0.1020(0.02730) *$ LN(age) & 0.010 \\
\hline SID/BWG & $Y=1.400(0.1200)-0.1006(0.03952) *$ LN(age) & 0.027 \\
\hline SID/FCR & $Y=1.468(0.0898)-0.0968(0.02829) * L N($ age $)$ & 0.014 \\
\hline
\end{tabular}

1): $Y=$ lysine content in the diet (\%).

The requirement values of AFD and SID lysine content at different ages are presented for BWG and FCR in Table 3.

Estimated AFD and SID lysine requirements for BWG are lower than for FCR. Until three weeks of age the AFD and SID lysine requirement for BWG are significantly higher than the CVB (2007) recommendations for AFD lysine requirement. AFD and SID lysine requirement for FCR are over the entire period significantly higher than the CVB (2007) recommendations for AFD lysine requirement. 


\section{Table 3}

Requirement of lysine content ( $\%$ of diets) according to the regression models for body weight gain and feed conversion ratio

\begin{tabular}{|c|c|c|c|c|c|}
\hline \multirow[t]{2}{*}{ Day } & \multirow{2}{*}{$\begin{array}{c}\text { AFD lysine ( } \% \text { in diet) } \\
\text { CVB (2007) }\end{array}$} & \multicolumn{2}{|c|}{ AFD lysine ( $\%$ in diet) } & \multicolumn{2}{|c|}{ SI D lysine ( $\%$ in diet) } \\
\hline & & Body weight gain & $\begin{array}{c}\text { Feed conversion } \\
\text { ratio }\end{array}$ & Body weight gain & $\begin{array}{c}\text { Feed conversion } \\
\text { ratio }\end{array}$ \\
\hline 5 & 1.05 & 1.22 & 1.30 & 1.24 & 1.31 \\
\hline 6 & 1.05 & 1.20 & 1.28 & 1.22 & 1.29 \\
\hline 7 & 1.05 & 1.19 & 1.26 & 1.20 & 1.28 \\
\hline 8 & 1.05 & 1.17 & 1.25 & 1.19 & 1.27 \\
\hline 9 & 1.05 & 1.16 & 1.24 & 1.18 & 1.26 \\
\hline 10 & 1.05 & 1.15 & 1.23 & 1.17 & 1.25 \\
\hline 11 & 1.05 & 1.14 & 1.22 & 1.16 & 1.24 \\
\hline 12 & 1.05 & 1.13 & 1.21 & 1.15 & 1.23 \\
\hline 13 & 1.05 & 1.12 & 1.20 & 1.14 & 1.22 \\
\hline 14 & 1.02 & 1.11 & 1.19 & 1.13 & 1.21 \\
\hline 15 & 1.02 & 1.11 & 1.18 & 1.13 & 1.21 \\
\hline 16 & 1.02 & 1.10 & 1.18 & 1.12 & 1.20 \\
\hline 17 & 1.02 & 1.09 & 1.17 & 1.11 & 1.19 \\
\hline 18 & 1.02 & 1.09 & 1.17 & 1.11 & 1.19 \\
\hline 19 & 1.02 & 1.08 & 1.16 & 1.10 & 1.18 \\
\hline 20 & 1.02 & 1.08 & 1.16 & 1.10 & 1.18 \\
\hline 21 & 1.02 & 1.07 & 1.15 & 1.09 & 1.17 \\
\hline 22 & 1.02 & 1.07 & 1.15 & 1.09 & 1.17 \\
\hline 23 & 1.02 & 1.06 & 1.14 & 1.08 & 1.16 \\
\hline 24 & 1.02 & 1.06 & 1.14 & 1.08 & 1.16 \\
\hline 25 & 1.02 & 1.05 & 1.13 & 1.08 & 1.16 \\
\hline 26 & 1.02 & 1.05 & 1.13 & 1.07 & 1.15 \\
\hline 27 & 1.02 & 1.04 & 1.12 & 1.07 & 1.15 \\
\hline 28 & 0.99 & 1.04 & 1.12 & 1.06 & 1.15 \\
\hline 29 & 0.99 & 1.04 & 1.12 & 1.06 & 1.14 \\
\hline 30 & 0.99 & 1.03 & 1.11 & 1.06 & 1.14 \\
\hline 31 & 0.99 & 1.03 & 1.11 & 1.05 & 1.14 \\
\hline 32 & 0.99 & 1.03 & 1.11 & 1.05 & 1.13 \\
\hline 33 & 0.99 & 1.02 & 1.10 & 1.05 & 1.13 \\
\hline 34 & 0.99 & 1.02 & 1.10 & 1.05 & 1.13 \\
\hline 35 & 0.99 & 1.02 & 1.10 & 1.04 & 1.12 \\
\hline 36 & 0.99 & 1.01 & 1.10 & 1.04 & 1.12 \\
\hline 37 & 0.99 & 1.01 & 1.09 & 1.04 & 1.12 \\
\hline 38 & 0.99 & 1.01 & 1.09 & 1.03 & 1.12 \\
\hline 39 & 0.99 & 1.01 & 1.09 & 1.03 & 1.11 \\
\hline 40 & 0.99 & 1.00 & 1.08 & 1.03 & 1.11 \\
\hline 41 & 0.99 & 1.00 & 1.08 & 1.03 & 1.11 \\
\hline 42 & 0.99 & 1.00 & 1.08 & 1.02 & 1.11 \\
\hline
\end{tabular}




\title{
Acknowledgement
}

The CVB project group 'Digestible Amino Acids Poultry', consisting of scientists and representatives of the Dutch feed industry, guided this study. The authors would like to acknowledge with much appreciation the members of this project group for their valuable input to all phases of this project. The members of the CVB project group 'Digestible Amino Acids Poultry' were:

\author{
Alfons Jansman \\ Bart Swart \\ Cees Kwakernaak \\ Carolien Makkink \\ Henk Everts \\ Machiel Blok \\ Marien van den Brink \\ Marinus van Krimpen \\ Mario van Erp \\ Masja Lensing \\ Peter Wijtten \\ Rene Kwakkel \\ Ruud Dekker \\ Teun Veldkamp \\ Walter Gerrits \\ Wouter Spek
}




\section{Literature}

Adedokun, S. A., C. M. Parsons, O. Adeola, M. Lilburn, and T. J. Applegate. 2008. Comparison of apparent and standardized amino acid digestibility of feed ingredients in cecectomized roosters, laying hens, and broilers. Poult. Sci. 87: 145-145.

Aftab, U., M. Ashraf, A. S. Mumtaz, Z. Jiang. 2007. Lysine requirement of broiler chickens fed lowdensity diets under tropical conditions. Asian-Aust. J. Anim. Sci. (20)6: 939-943.

Berri, C., J. Besnard, C. Relandeau. 2008. Increasing Dietary Lysine Increases Final pH and Decreases Drip Loss of Broiler Breast Meat. Poultry Science 87:480-484.

Campestrini, E., M.J.B. Barbosa, R.V. Nunes, E. Gasparino, W.T.M. da Silva, R. Khül. 2010. Level digestible lysine with two electrolyte balances for broiler chicks at the starting phase (1-21 day). R. Bras. Zootec., v.39, n.1, p.151-157.

Coca-Sinova, A., E. Jeménez-Moreno, J.M. González-Alvarado, M. Frikha, R. Lázaro, G.G. Mateos. 2010. Influence of source of soybean meal and lysine content of the diet on performance and total tract apparent retention of nutrients in broilers from 1 to 36 days of age. Poultry Science 89: 14401450.

Corzo, A., L. Mejia, C.D. McDaniel, J.S. Mortiz. 2012. Interactive effects of feed form and dietary lysine on growth responses of commercial broiler chicks. J. Appl. Poult. Res. 21 :70-78.

CVB. 1996. Amino acid requirement of laying hens and broiler chicks. Schutte, J.B. (ed.). CVB Report No. 18.

CVB. 2007. Veevoedertabel 2007, centraal veevoederbureau. Lelystad, The Netherlands. Uitgave mei 2007.

Dekker, R., and M. C. Blok. 2015 (in press). Gestandaardiseerde ileale aminozuurverteerbaarheid van voedermiddelen voor pluimvee. DVAZP 43.

Dozier, W.A., A. Corzo, M.T. Kidd, P.B. Tillman, S.L. Branton. 2009. Digestible lysine requirements of male and female broilers from fourteen to twenty-eight days of age. Poultry Science $88: 1676$ 1682.

Dozier, W.A., A. Corzo, M.T. Kidd, P.B. Tillman, J.P. McMurtry, S.L. Branton. 2010. Digestible lysine requirements of male broilers from 28 to 42 days of age. Poultry Science 89 :2173-2182.

Dozier, W.A., R.L. Payne. 2012. Digestible lysine requirements of female broilers from 1 to 15 days of age. J. Appl. Poult. Res. 21 :348-357.

Fatufe, A.A., R. Timmler, M. Rodehutscord. 2004. Response to Lysine Intake in Composition of Body Weight Gain and Efficiency of Lysine Utilization of Growing Male Chickens from Two Genotypes. Poultry Science 83: 1314-1324.

Garcia, A.R., A.B. Batal, D.H. Baker. 2006. Variations in the Digestible Lysine Requirement of Broiler Chickens Due to Sex, Performance Parameters, Rearing Environment, and Processing Yield Characteristics. Poultry Science 85:498-504

Hassan, H.M.A., M.A. Mohamed, T.M. El-Afifi. 2011. Effect of phytase or lysine supplementation on performance of broilers fed lysine deficient diet from 21 to 42 days of age. Department of Animal Production, National Research Centre, 12622, Dokki, Egypt. Received: 26/02/2011. Accepted: 06/03/2011.

Knowles, T.A., L.L. Southern. 1998. The Lysine Requirement and Ratio of Total Sulfur Amino Acids to Lysine for Chicks Fed Adequate or Inadequate Lysine. Poultry Science 77:564-569.

Lemme, A., P.J.A. Wijtten, J. van Wichen, A. Petri, D.J. Langhout. 2006. Responses of Male Growing Broilers to Increasing Levels of Balanced Protein Offered as Coarse Mash or Pellets of Varying Quality. Poultry Science 85:721-730.

Lemme, A., V. Ravindran, and W. L. Bryden. 2004. Ileal digestibility of amino acids in feed ingredients for broilers. Worlds Poult. Sci. J. 60(4):423-437. 
Mack, S., D. Bercovici, G. De Groote, B. Leclerq, M. Lippens, M. Pack, J.B. Schutte, S. Van Cauwenberghe. 1999. I deal amino acid profile and dietary lysine specification for broiler chickens of 20 to 40 days of age. British Poultry Science. 40 (2): 257 - 265.

Mahdavi, A., M. Shivazad, F. Alemi, M. Zaghari, H. Moravej, B. Darabighane. 2012. Digestible lysine requirement of broilers based on practical diet. Italian J ournal of Animal Science 2012; volume 11:e13: 68-76.

Mehri, M., H. Nassiri-Moghaddam, H. Kermanshahi, M. Danesh-Mesgaran. 2010. Digestible lysine requirements of straight-run broiler chickens form fifteen to twenty-eight days of age. Journal of Animal and Veterinary Advances 9(17): 2321-2324.

Panda, A.K., S.V. Rama Rao, M.V.L.N. Raju, G. Lavanya, E.P.K. Reddy, G.S. Sunder. 2011. Early Growth Response of Broilers to Dietary Lysine at Fixed Ratio to Crude Protein and Essential Amino Acids. Asian-Aust. J. Anim. Sci. Vol. 24, No. 11 : 1623 - 1628.

St-Pierre, N.R. 2001. I nvited review: Integrating quantitative findings from multiple studies using mixed model methodology. J. Dairy Sci. 84:741-755.

Strathe, A.B., A. Lemme, J.K. Htoo, E. Kebreab. 2011. Estimating digestible methionine requirements for laying hens using multivariate nonlinear mixed effect models. Poultry Science 90 :1496- 1507.

Takeara, P., A.L. Toledo, E.R.S. Gandra, R. Albuquerque, M.A. Trindade Neto. 2010. Digestible lysine for male broilers from 12 to 22 days of age. Arq. Bras. Med. Vet. Zootec., v.62, n.6, p.1455-1461.

Toledo, R.S., H.S. Rostagno, L.F.T. Albino, M.A. Dionizio, D.C. de Oliveira Carvalho, E.T. Nogueira. 2011. Lysine nutritional requirements of broilers reared in clean and dirty environments during the prestarter and starter phases. R. Bras. Zootec., v.40, n.10, p.2205-2210.

Trindade Neto, M.A., A.L. de Toledo, P. Takeara, E. Kobashigawa, D.C.Z. Donato, R. de Albuquerque. 2011. Dietary levels of lysine for male broilers from 23 to 36 days of age: performance and body composition. R. Bras. Zootec., v.40, n.3, p.609-615, 2011.

Trindade Neto, M.A., L.B. Namazu, E. Kobashigawa, P. Takeara, D.C.Z. Donato, R. de Albuquerque. 2011. Digestible lysine and organic zinc for male broiler from 1 to 11 days of age: performance and body composition. R. Bras. Zootec., v.40, n.3, p.602-608.

Van Houwelingen, H.C., L.R. Arends, T. Stijnen. 2002. Advanced methods in meta-analysis: Multivariate approach and meta-regression. Stat. Med. 21:589-624.

Wijtten, P.J.A., A. Lemme, D.J. Langhout. 2004. Effects of Different Dietary Ideal Protein Levels on Male and Female Broiler Performance During Different Phases of Life: Single Phase Effects, Carryover Effects, and Interactions Between Phases. Poultry Science 83:2005-2015.

Wijtten, P.J.A., R. Prak, A. Lemme., D.J. Langhout 2004. Effect of different dietary ideal protein concentrations on broiler performance. British Poultry Science Volume 45, Number 4 (August 2004), pp. 504-511. 
Appendices 


\section{Appendix 1 List of references which have not been included in the database with reason}

\begin{tabular}{|c|c|c|}
\hline Reference & Journal & Reason \\
\hline Knowles \& Southern (1998) & Poultry Sci: 77:564-569 & $\begin{array}{l}\text { Experiment was done in a factorial arrangement (lys } \times \text { TSAA) and there were no data for performance (weight } \\
\text { gain \& feed intake) per factor because of interactions. }\end{array}$ \\
\hline Wijtten et al. (2004) & British poultry Sci: $45: 504-511$ & There were only 2 levels of lysine \\
\hline Wijtten et al. (2004) & Poultry Sci: 83:2005-2015 & There were only 2 levels of lysine \\
\hline Lemme et al. (2006) & Poultry Sci: $85: 721-730$ & $\begin{array}{l}\text { Experiment was done in a factorial arrangement and there were no data for performance (weight gain } \& \text { feed } \\
\text { intake) per factor because of interactions. }\end{array}$ \\
\hline Garcia et al. (2006) & Poultry Science $85: 498-504$ & Study 9 and 11: no statistical significant effect on BWG and/or FCR \\
\hline Garcia et al. (2006) & Poultry Science $85: 498-504$ & Study 13 and 14 : sum of ingredient composition $<100 \%$ \\
\hline Usama Aftab et al., 2007 & Asian-Aust. J. Anim. Sci & Second study: M+C and THR $<-5 \%$ and ILE and VAL $<-10 \%$ of limited level \\
\hline Takeara et al., 2010 & R. Bras. Zootec. & LYS $>-10 \%$ of limited level \\
\hline Campestrini et al., 2010 & R. Bras. Zootec. & LYS >- $10 \%$ of limited level \\
\hline Dozier et al. (2010) & Poultry Sci. 89: 2173-2182 & $\begin{array}{l}\text { Diet dilution technique was used for creating the graded levels of diets and final diets were made by blending a } \\
\text { high-lysine diet with a low-Lysine diet, therefore recalculation of diets according to CVB was not possible }\end{array}$ \\
\hline Coca-sinova et al. (2010) & Poultry Sci. 89:1440-1450 & $\begin{array}{l}\text { Experiment was done in a factorial arrangement (lys xtype of soybean meal) and there were no data for } \\
\text { performance (weight gain \& feed intake) per factor because of interactions. }\end{array}$ \\
\hline Trindade Neto et al. (2011) & R. Bras. Zootec: 40:602-608 & Data for feed intake were not given. \\
\hline Cuevas A et al. (2011) & Rev. Mex. Cienc: 2:259-266 & Diets were formulated in a wrong way and data were not valid \\
\hline Rodrigo Santana Toledo et al. 2011 & Revista Brasileira de Zootecnia & LYS $>-10 \%$ of limiting level \\
\hline Trindade Neto et al, 2011 & Revista Brasileira de Zootecnia & LYS $>-10 \%$ of limiting level \\
\hline Hassan et al., 2011 & www.epsaegypt.com/pdf & $M+C<-10 \%$ of limited level \\
\hline Neto et al., 2011 & R. Bras. Zootec. & $M+C<-10 \%$ of limited level \\
\hline Panda et al., 2011 & Asian-Aust. J. Anim. Sci. & THR and VAL $<-10 \%$ of limited level \\
\hline Corzo et al. (2012) & J. appl. Poultry Sci: 21:70-78 & $\begin{array}{l}\text { Experiment was done in a factorial arrangement (lys } \times \text { Diet texture) and there were no data for performance } \\
\text { (weight gain } \& \text { feed intake) per factor because of interactions. }\end{array}$ \\
\hline
\end{tabular}


Appendix 2 The determined responses of body weight gain ( $g / d)$ as a function of the AFD and SID lysine content for each individual experiment ( $\% \mathrm{CV}=$ coefficient of variation; in brackets)

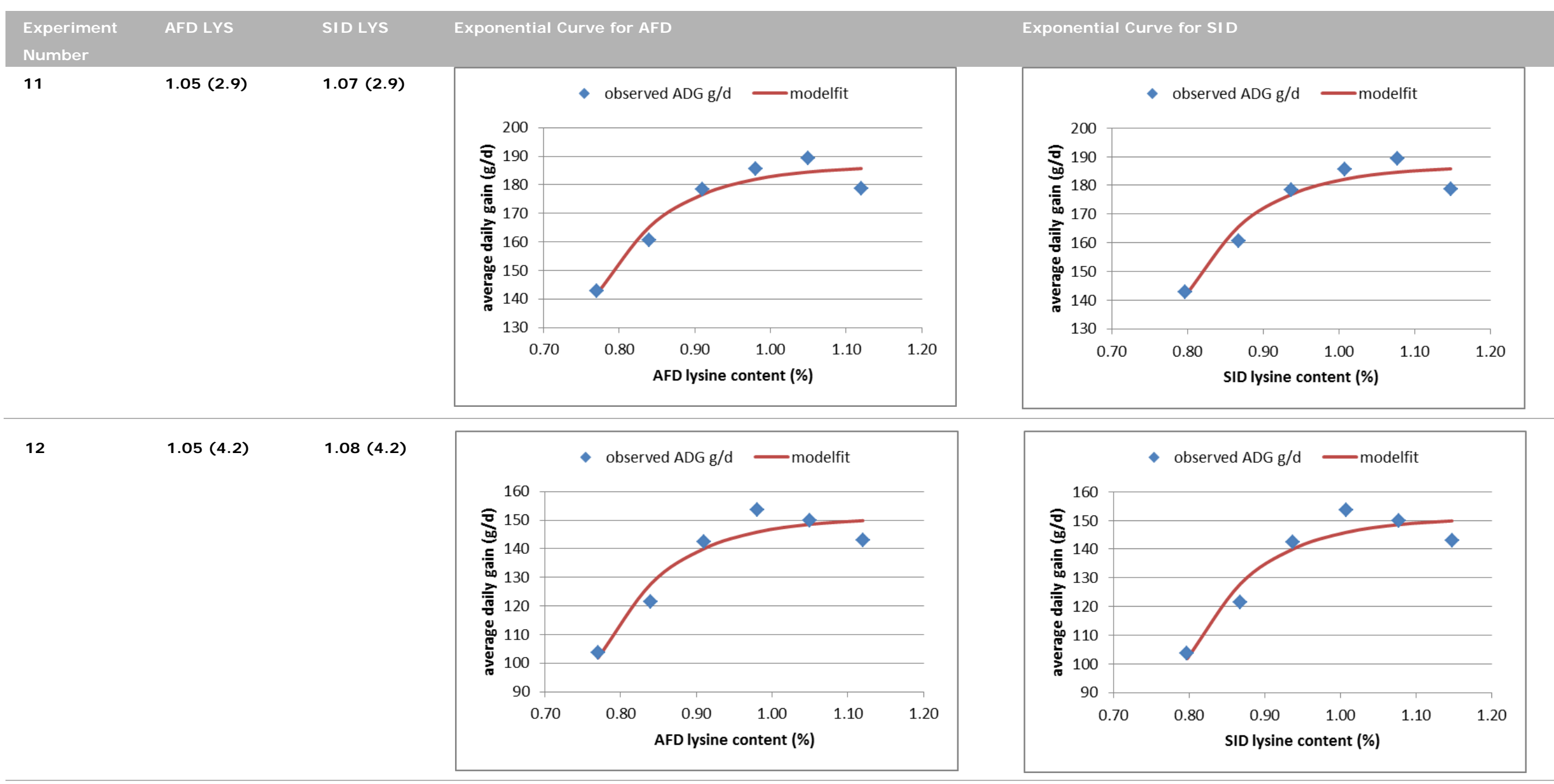




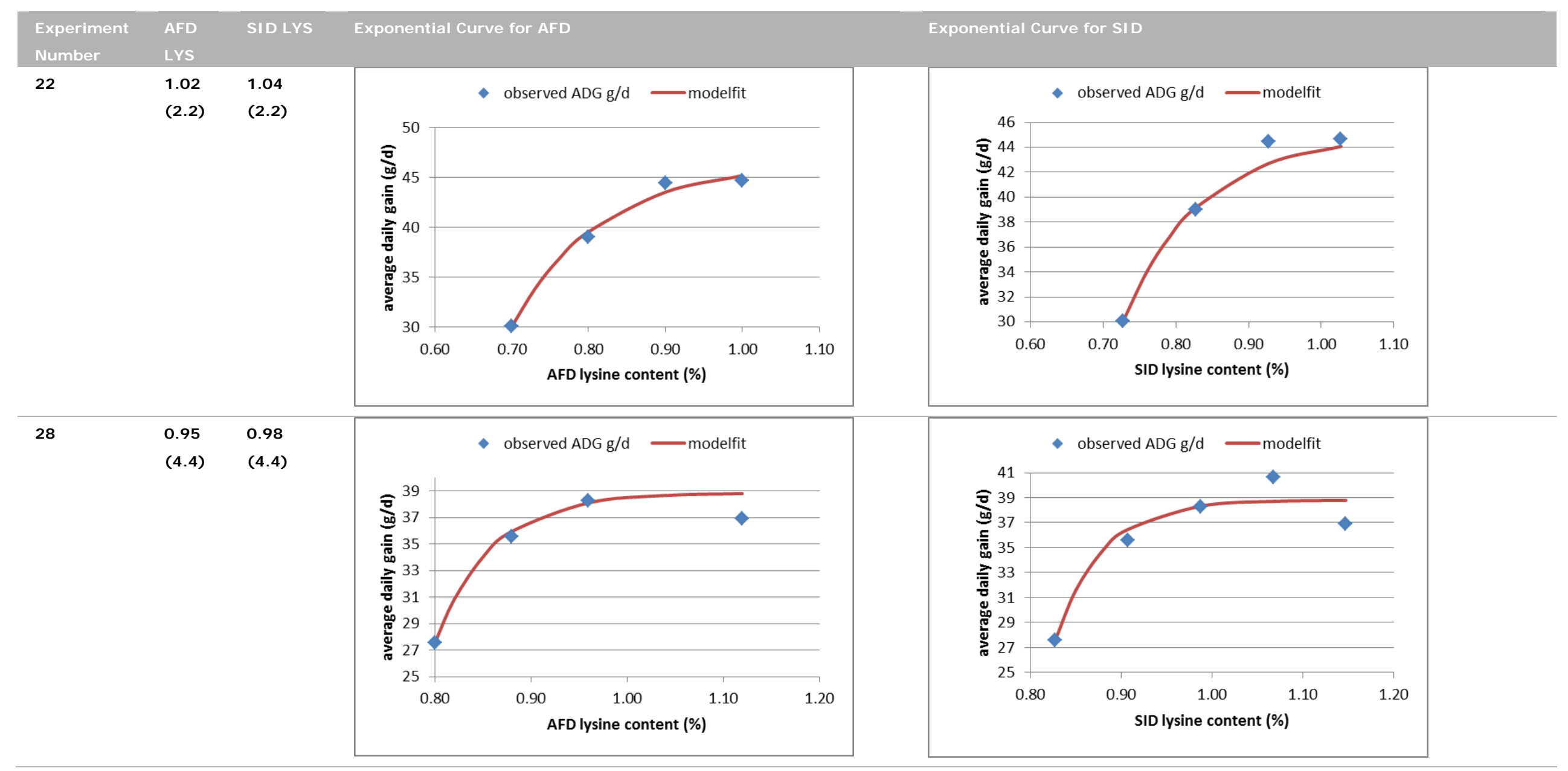




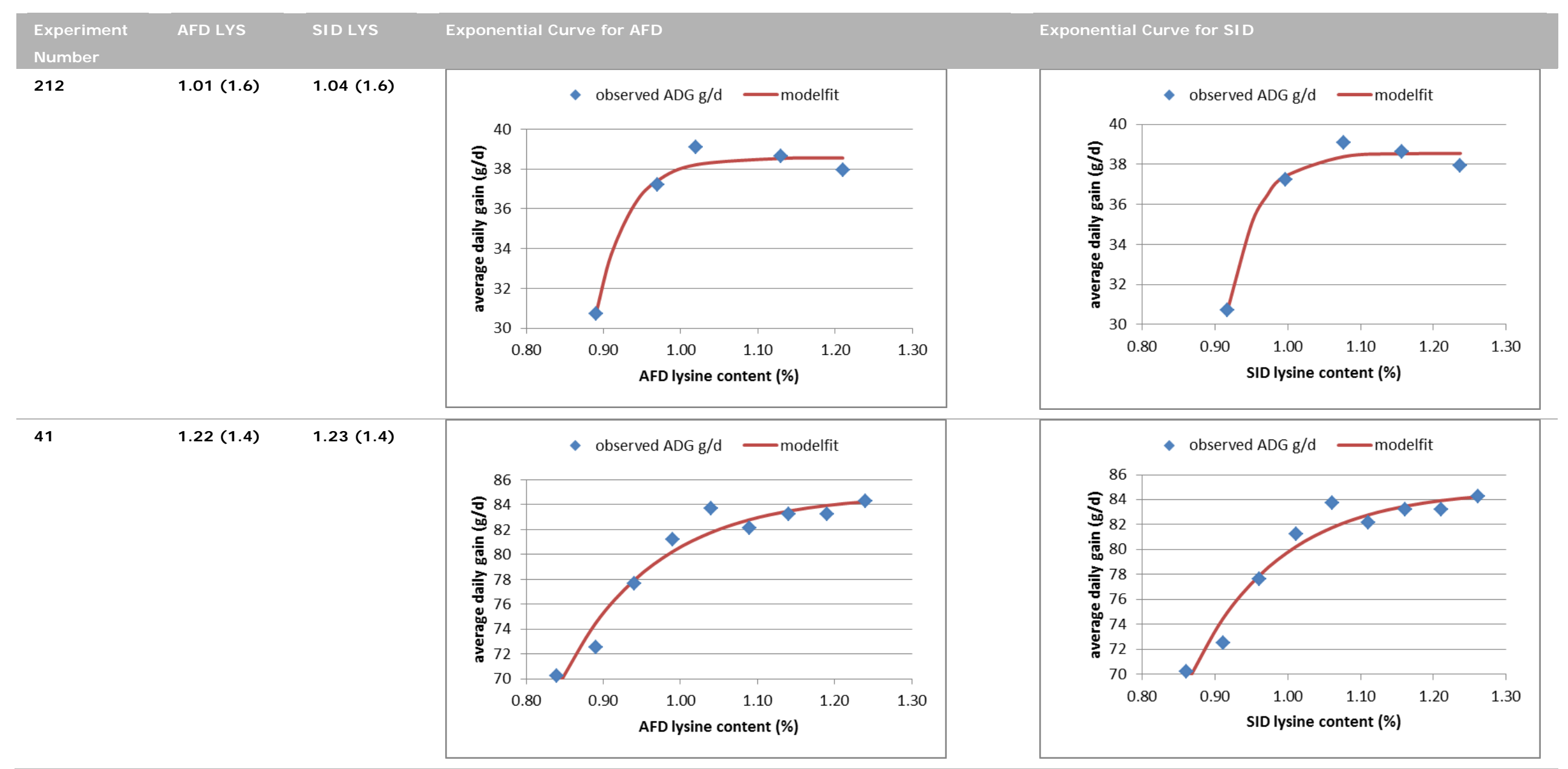




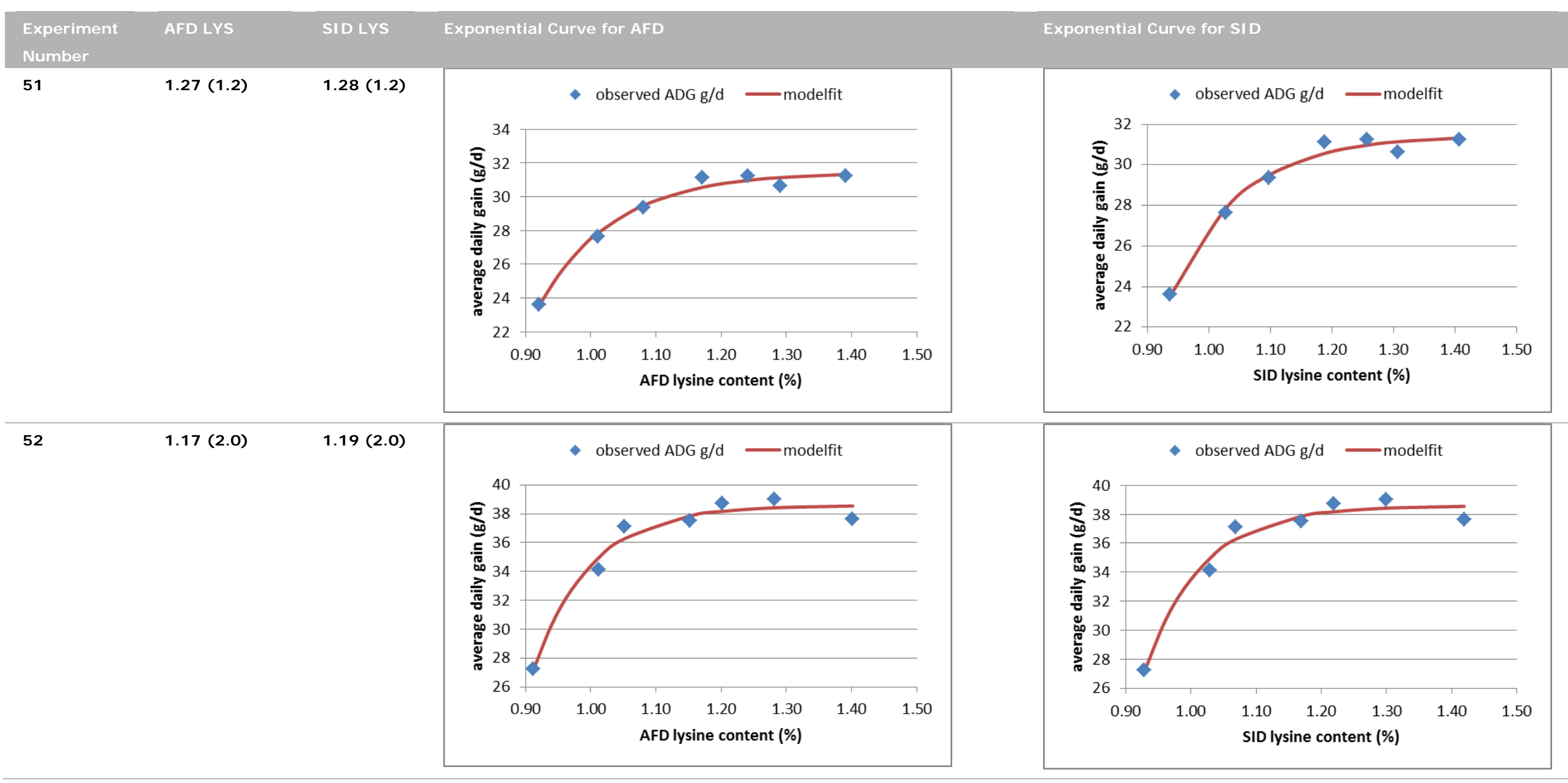




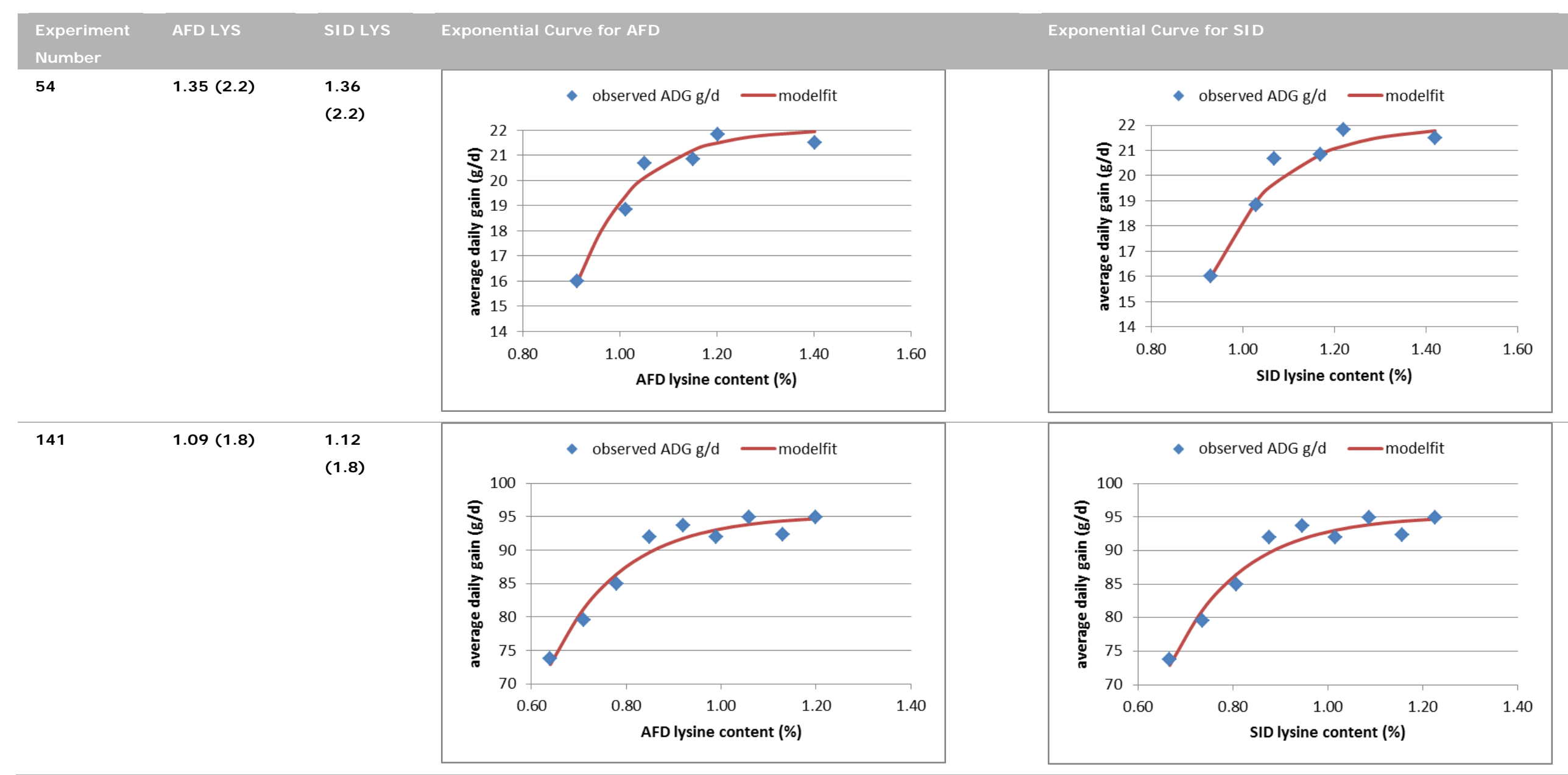




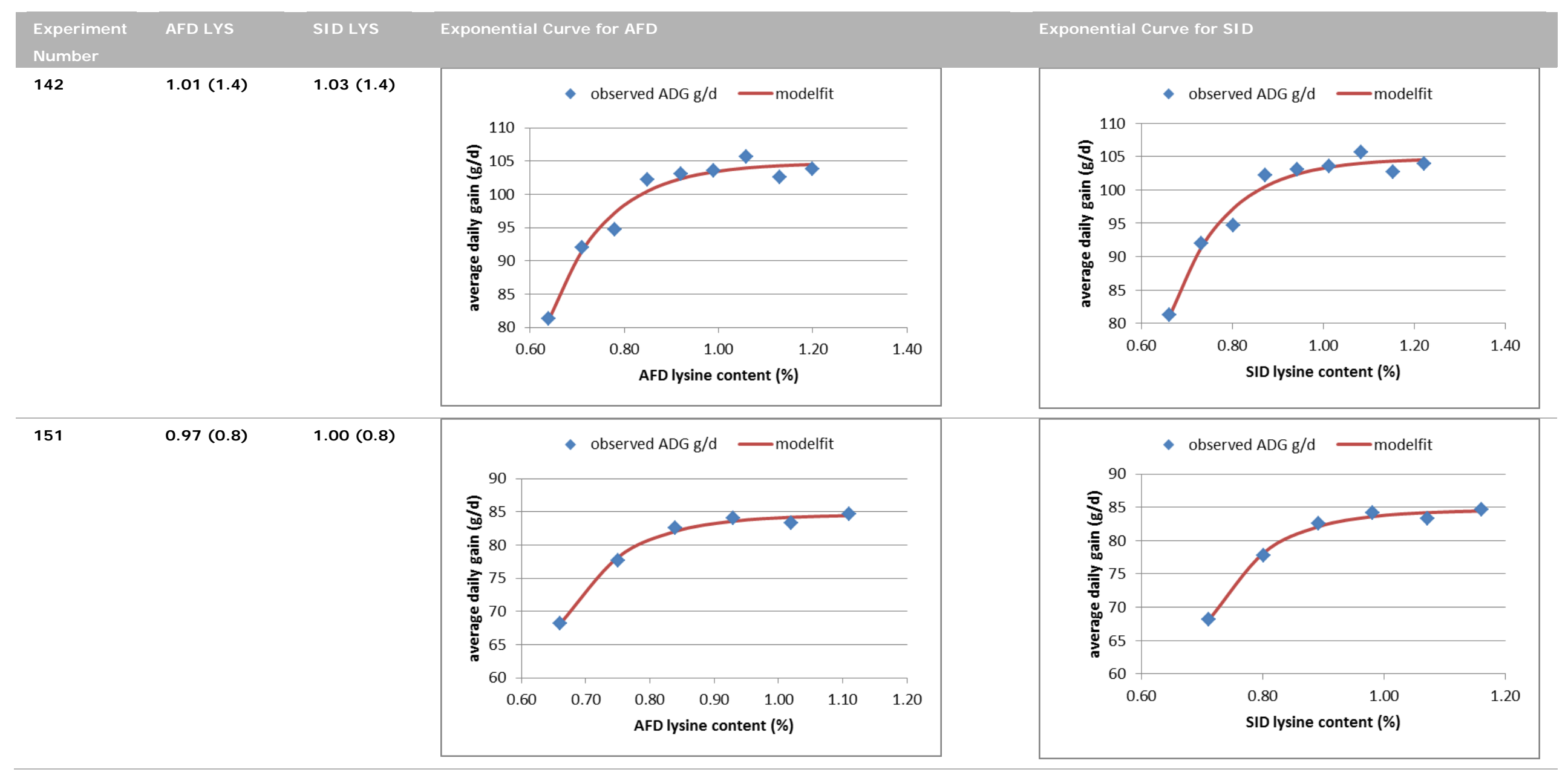




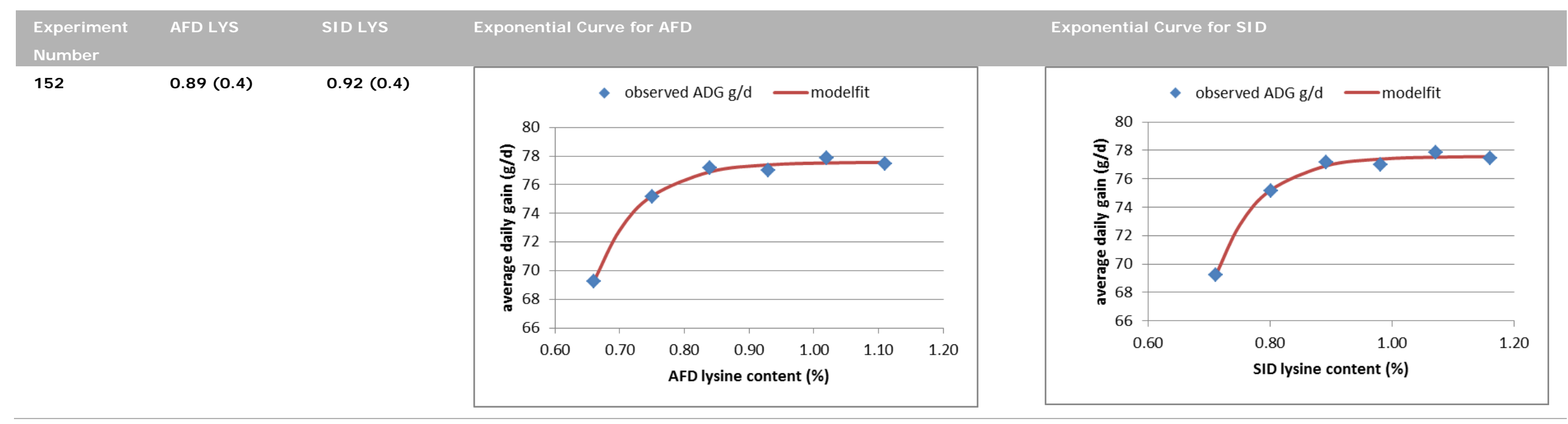


Appendix 3 The determined responses of feed conversion ratio as a function of the AFD and SID lysine content for each individual experiment ( $\% \mathrm{CV}=$ coefficient of variation; in brackets)

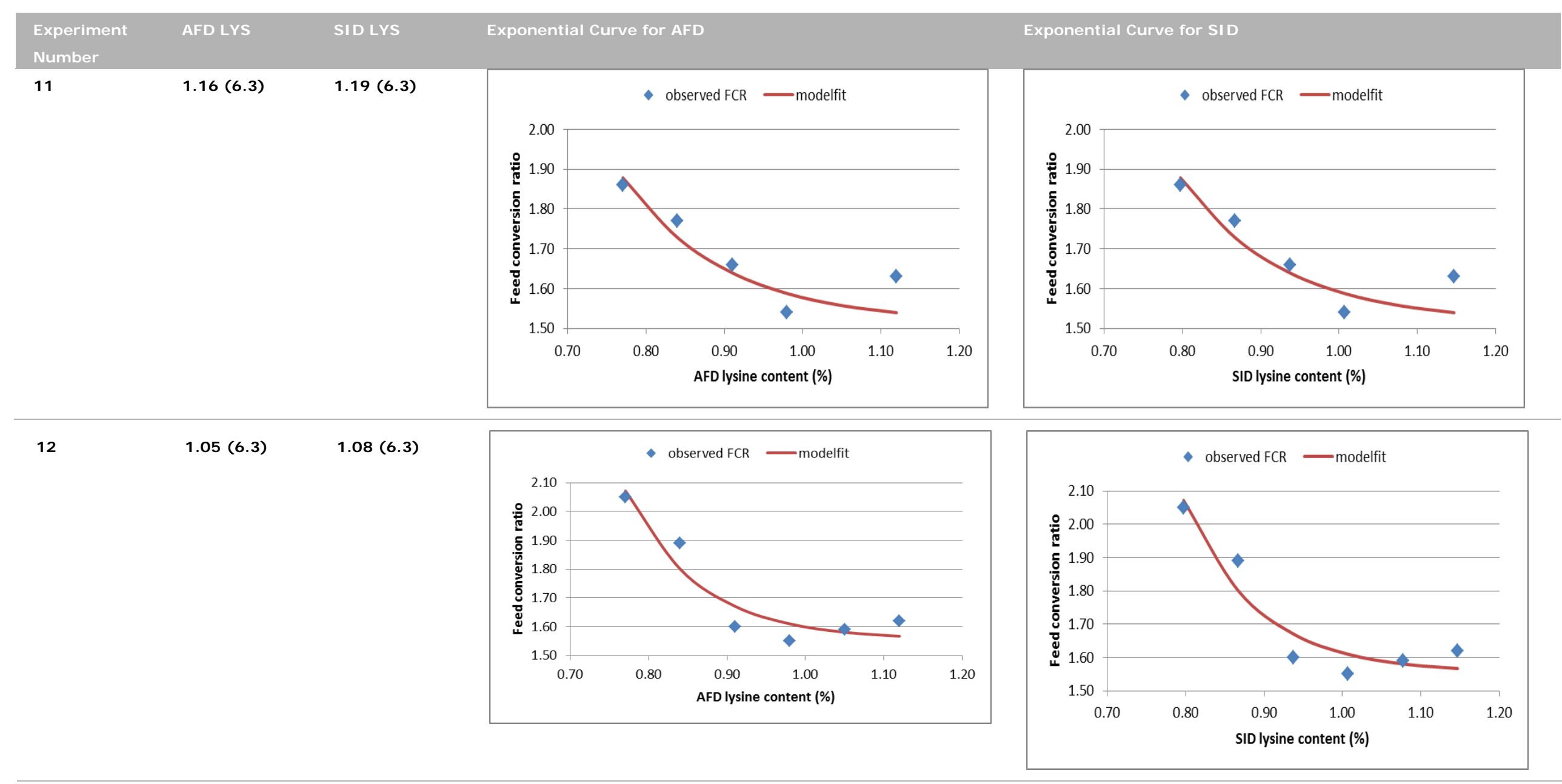




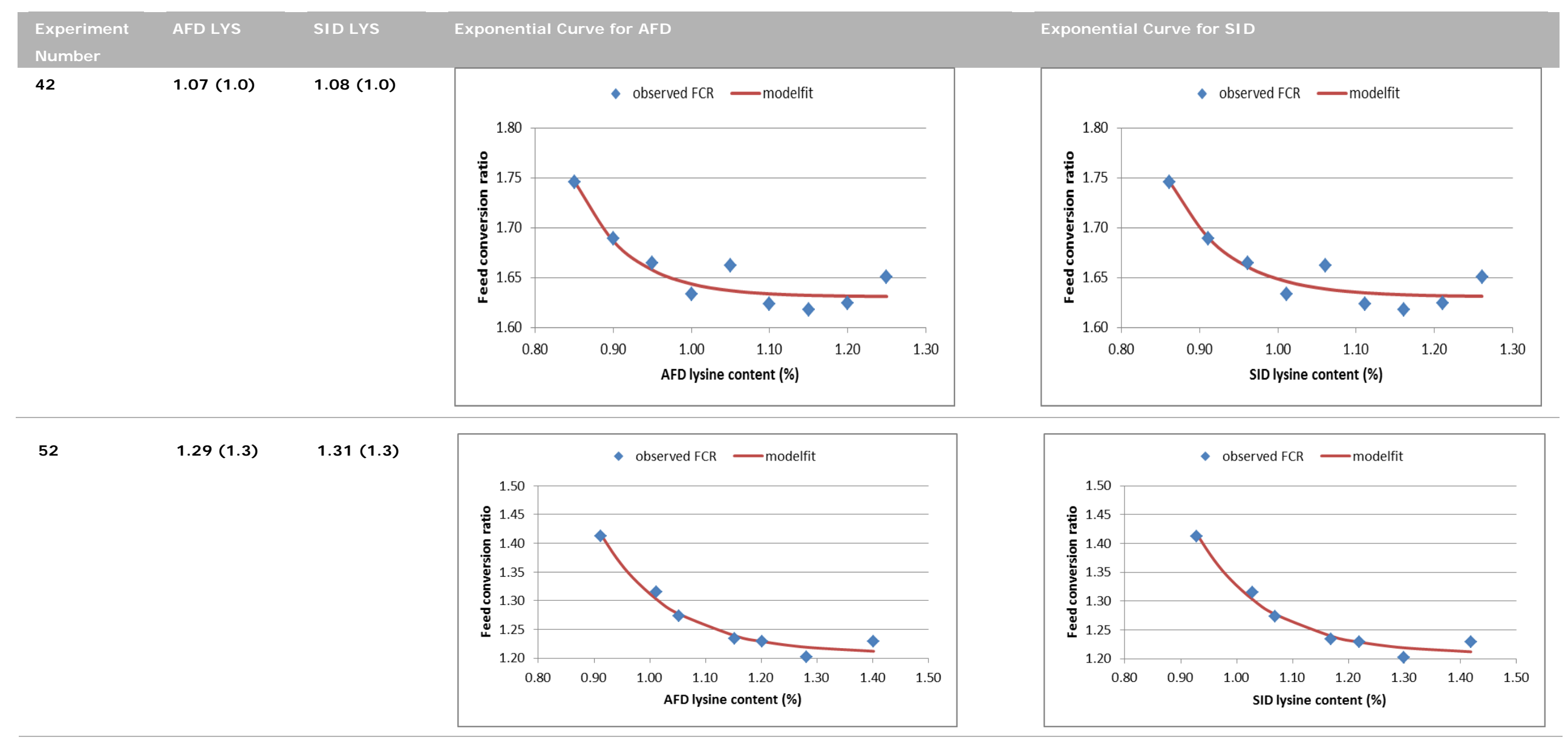




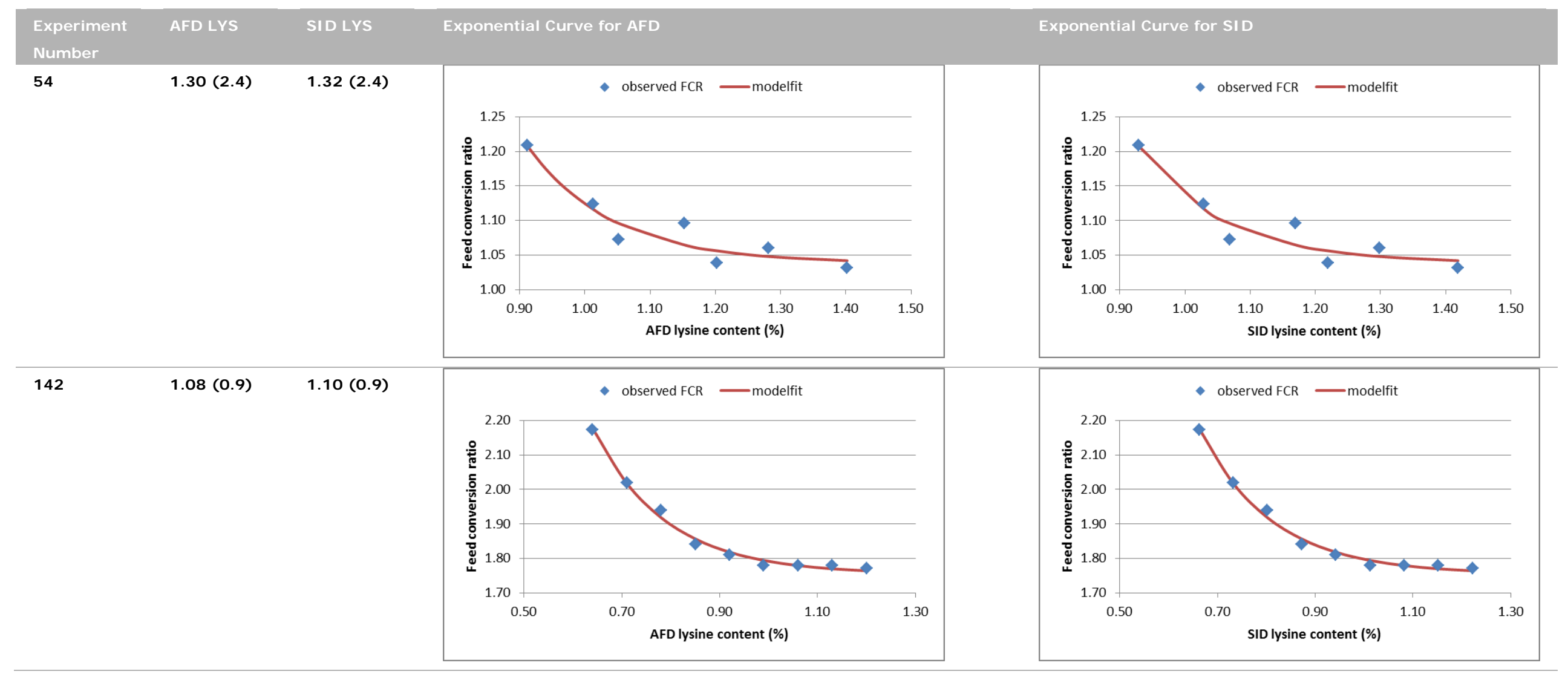




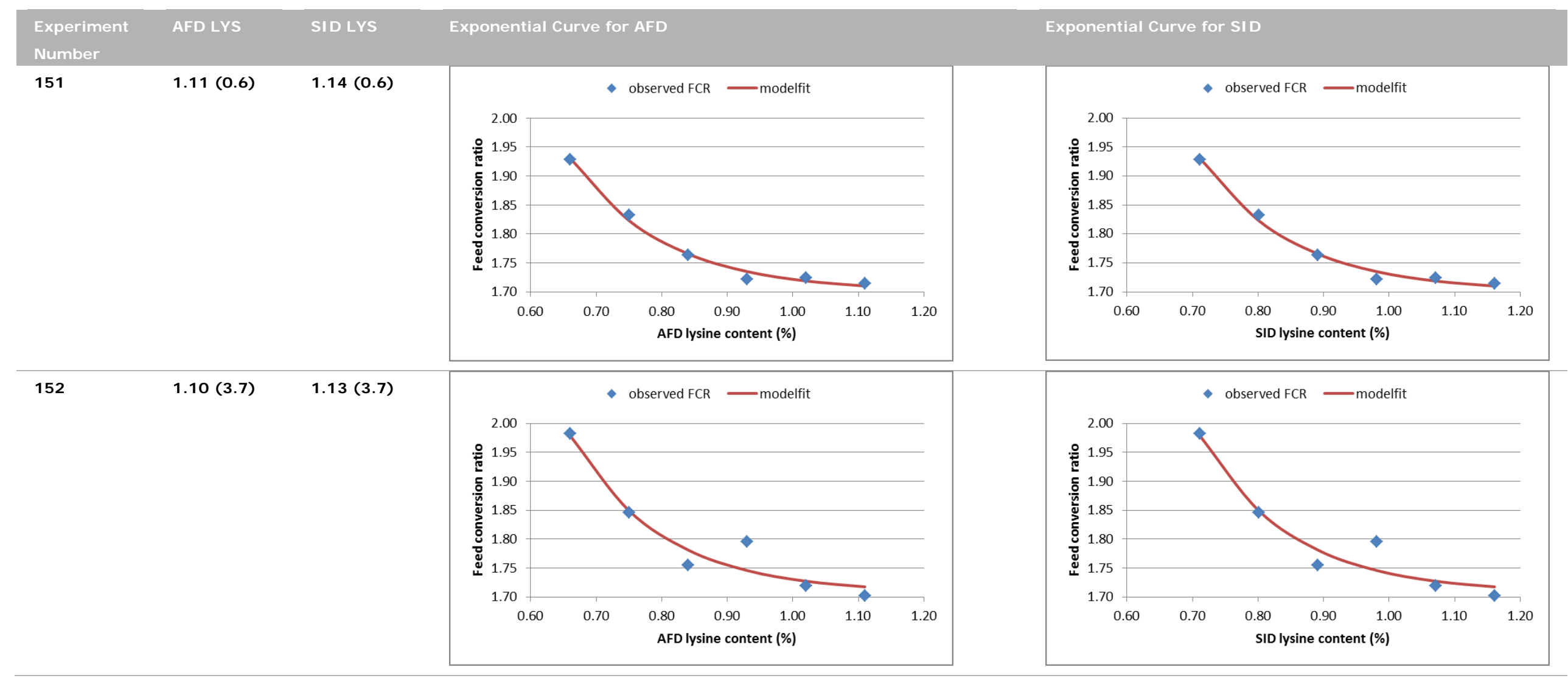


Appendix 4 Experiments for which the requirement on the AFD and SID lysine concentration for BWG was estimated according to equation 2 and that also met the criteria for the overall regression to estimate the relationship of the AFD and SID lysine requirement for BWG with age

\begin{tabular}{|c|c|c|c|c|c|c|c|c|c|}
\hline \multirow[t]{2}{*}{$\begin{array}{l}\text { Exp } \\
\text { No. }\end{array}$} & \multirow[t]{2}{*}{ Reference } & \multirow[t]{2}{*}{$\begin{array}{l}\text { AFD lysine concentration in } \\
\text { the diet }(\%)\end{array}$} & \multirow[t]{2}{*}{ Gender } & \multirow[t]{2}{*}{ Strain } & \multirow[t]{2}{*}{$\begin{array}{l}\text { Age of } \\
\text { birds }\end{array}$} & \multirow{2}{*}{$\begin{array}{l}\text { Published } \\
\text { Requirement } \\
(\%)\end{array}$} & \multirow[t]{2}{*}{$\begin{array}{l}\text { Models used by the } \\
\text { reference }\end{array}$} & \multicolumn{2}{|c|}{$\begin{array}{l}\text { Re-calculated requirement using } \\
\text { exponential models }(\%)\end{array}$} \\
\hline & & & & & & & & $\begin{array}{l}\text { AFD lysine } \\
\text { content for BWG }\end{array}$ & $\begin{array}{l}\text { SID lysine } \\
\text { content for BWG }\end{array}$ \\
\hline 11 & $\begin{array}{l}\text { Mahdavi et al } \\
(2012)\end{array}$ & $\begin{array}{l}0.77,0.84,0.91,0.98,1.05 \\
1.12\end{array}$ & Male & - & $35-49$ & 0.98 & $\begin{array}{l}\text { Broken-line, } \\
\text { exponential, quadratic }\end{array}$ & 1.05 & 1.07 \\
\hline 12 & $\begin{array}{l}\text { Mahdavi et al } \\
(2012)\end{array}$ & $\begin{array}{l}0.77,0.84,0.91,0.98,1.05 \\
1.12\end{array}$ & Female & - & $35-49$ & 0.93 & $\begin{array}{l}\text { Broken-line, } \\
\text { exponential, quadratic }\end{array}$ & 1.05 & 1.08 \\
\hline 22 & $\begin{array}{l}\text { Garcia et al } \\
\text { (2006) }\end{array}$ & $0.70,0.80,0.90,1.00$ & Male & Cobb & $7-21$ & 0.93 & Lineair and Quadratic & 1.04 & 1.07 \\
\hline 28 & $\begin{array}{l}\text { Garcia et al } \\
\text { (2006) }\end{array}$ & $0.80,0.88,0.96,1.04,1.12$ & Female & Cobb & $7-21$ & 0.97 & Lineair and Quadratic & 0.98 & 1.00 \\
\hline 212 & $\begin{array}{l}\text { Garcia et al } \\
\text { (2006) }\end{array}$ & $0.89,0.97,1.02,1.13,1.21$ & Female & Cobb & $7-21$ & 0.99 & Lineair and Quadratic & 1.01 & 1.04 \\
\hline 41 & $\begin{array}{l}\text { Dozier et al } \\
(2009)\end{array}$ & $\begin{array}{l}0.85,0.90,0.95,1.00,1.05 \\
1.10,1.15,1.20,1.25\end{array}$ & Male & Ross & $14-28$ & 1.15 & Broken-line & 1.22 & 1.23 \\
\hline 51 & $\begin{array}{l}\text { Dozier \& Payne } \\
\text { (2012) }\end{array}$ & $\begin{array}{l}0.91,1.01,1.05,1.15,1.20 \\
1.28,1.40\end{array}$ & Female & Ross & 7-15 & - & Quadratic broken line & 1.27 & 1.28 \\
\hline 52 & $\begin{array}{l}\text { Dozier \& Payne } \\
(2012)\end{array}$ & $\begin{array}{l}0.91,1.01,1.05,1.15,1.20 \\
1.28,1.40\end{array}$ & Female & Hubbard $\times$ Cobb & $7-15$ & - & Quadratic broken line & 1.17 & 1.19 \\
\hline 54 & $\begin{array}{l}\text { Dozier \& Payne } \\
\text { (2012) }\end{array}$ & $\begin{array}{l}0.91,1.01,1.05,1.15,1.20 \\
1.28,1.40\end{array}$ & Female & Hubbard $\times$ Cobb & $1-7$ & 1.35 & Quadratic broken line & 1.27 & 1.29 \\
\hline
\end{tabular}




\begin{tabular}{|c|c|c|c|c|c|c|c|c|c|}
\hline \multirow[t]{2}{*}{$\begin{array}{l}\text { Exp } \\
\text { No. }\end{array}$} & \multirow[t]{2}{*}{ Reference } & \multirow[t]{2}{*}{$\begin{array}{l}\text { AFD lysine concentration in } \\
\text { the diet }(\%)\end{array}$} & \multirow[t]{2}{*}{ Gender } & \multirow[t]{2}{*}{ Strain } & \multirow[t]{2}{*}{$\begin{array}{l}\text { Age of } \\
\text { birds }\end{array}$} & \multirow{2}{*}{$\begin{array}{l}\text { Published } \\
\text { Requirement } \\
(\%)\end{array}$} & \multirow[t]{2}{*}{$\begin{array}{l}\text { Models used by the } \\
\text { reference }\end{array}$} & \multicolumn{2}{|c|}{$\begin{array}{l}\text { Re-calculated requirement using } \\
\text { exponential models }(\%)\end{array}$} \\
\hline & & & & & & & & $\begin{array}{l}\text { AFD lysine } \\
\text { content for BWG }\end{array}$ & $\begin{array}{l}\text { SID lysine } \\
\text { content for BWG }\end{array}$ \\
\hline 141 & $\begin{array}{l}\text { Dozier et al } \\
(2010)\end{array}$ & $\begin{array}{l}0.64,0.71,0.78,0.85,0.92 \\
0.99,1.06,1.13,1.20\end{array}$ & Male & Ross & $28-42$ & 1.05 & Quadratic broken line & 1.09 & 1.12 \\
\hline 142 & $\begin{array}{l}\text { Dozier et al } \\
(2010)\end{array}$ & $\begin{array}{l}0.64,0.71,0.78,0.85,0.92 \\
0.99,1.06,1.13,1.20\end{array}$ & Male & Cobb & $28-42$ & 1.01 & Quadratic broken line & 1.01 & 1.03 \\
\hline 151 & $\begin{array}{l}\text { Mack et al } \\
\text { (1999) }\end{array}$ & $\begin{array}{l}0.66,0.75,0.84,0.93,1.02 \\
1.11\end{array}$ & Male & Ross & $20-40$ & 1.01 & $\begin{array}{l}\text { Broken-line, } \\
\text { exponential }\end{array}$ & 0.97 & 1.00 \\
\hline 152 & $\begin{array}{l}\text { Mack et al } \\
\text { (1999) }\end{array}$ & $\begin{array}{l}0.66,0.75,0.84,0.93,1.02 \\
1.11\end{array}$ & Male & ISA & $20-40$ & 1.10 & $\begin{array}{l}\text { Broken-line, } \\
\text { exponential }\end{array}$ & 0.89 & 0.92 \\
\hline
\end{tabular}


Appendix 5 Experiments for which the requirement on the AFD and SID lysine concentration for FCR was estimated according to equation 2 and that also met the criteria for the overall regression to estimate the relationship of the AFD and SID lysine requirement for FCR with age

\begin{tabular}{|c|c|c|c|c|c|c|c|c|c|}
\hline \multirow[t]{2}{*}{$\begin{array}{l}\text { Exp } \\
\text { No. }\end{array}$} & \multirow[t]{2}{*}{ Reference } & \multirow[t]{2}{*}{$\begin{array}{l}\text { SI D Iysine concentration in } \\
\text { the diet }(\%)\end{array}$} & \multirow[t]{2}{*}{ Gender } & \multirow[t]{2}{*}{ Strain } & \multirow[t]{2}{*}{$\begin{array}{l}\text { Age of } \\
\text { birds }\end{array}$} & \multirow{2}{*}{$\begin{array}{l}\text { Published } \\
\text { Require-ment } \\
(\%)\end{array}$} & \multirow[t]{2}{*}{$\begin{array}{l}\text { Models used by the } \\
\text { reference }\end{array}$} & \multicolumn{2}{|c|}{$\begin{array}{l}\text { Re-calculated requirement using } \\
\text { exponential models (\%) }\end{array}$} \\
\hline & & & & & & & & $\begin{array}{l}\text { AFD lysine } \\
\text { content } \\
\text { for FCR }\end{array}$ & $\begin{array}{l}\text { SID lysine content } \\
\text { for FCR }\end{array}$ \\
\hline 11 & $\begin{array}{l}\text { Mahdavi et al } \\
\text { (2012) }\end{array}$ & $\begin{array}{l}0.80,0.87,0.94,1.01,1.08 \\
1.15\end{array}$ & Male & - & $35-49$ & 0.98 & $\begin{array}{l}\text { Broken-line, } \\
\text { exponential, quadratic }\end{array}$ & 1.16 & 1.19 \\
\hline 12 & $\begin{array}{l}\text { Mahdavi et al } \\
(2012)\end{array}$ & $\begin{array}{l}0.80,0.87,0.94,1.01,1.08 \\
1.15\end{array}$ & Female & - & $35-49$ & 0.93 & $\begin{array}{l}\text { Broken-line, } \\
\text { exponential, quadratic }\end{array}$ & 1.05 & 1.08 \\
\hline 42 & $\begin{array}{l}\text { Dozier et al } \\
(2009)\end{array}$ & $\begin{array}{l}0.86,0.91,0.96,1.01,1.06 \\
1.11,1.16,1.21,1.26\end{array}$ & Male & Ross & $14-28$ & 1.15 & Broken-line & 1.07 & 1.08 \\
\hline 52 & $\begin{array}{l}\text { Dozier \& Payne } \\
\text { (2012) }\end{array}$ & $\begin{array}{l}0.93,1.03,1.07,1.17,1.22 \\
1.30,1.42\end{array}$ & Female & Hubbard ×Cobb & $7-15$ & 1.26 & Quadratic broken line & 1.29 & 1.31 \\
\hline 54 & $\begin{array}{l}\text { Dozier \& Payne } \\
(2012\end{array}$ & $\begin{array}{l}0.93,1.03,1.07,1.17,1.22 \\
1.30,1.42\end{array}$ & Female & Hubbard ×Cobb & $1-7$ & - & Quadratic broken line & 1.30 & 1.32 \\
\hline 142 & $\begin{array}{l}\text { Dozier et al } \\
(2010)\end{array}$ & $\begin{array}{l}0.66,0.73,0.80,0.87,0.94 \\
1.01,1.08,1.15,1.22\end{array}$ & Male & Cobb & $28-42$ & 1.01 & Quadratic broken line & 1.08 & 1.10 \\
\hline 151 & $\begin{array}{l}\text { Mack et al } \\
\text { (1999) }\end{array}$ & $\begin{array}{l}0.71,0.80,0.89,0.98,1.07 \\
1.16\end{array}$ & Male & Ross & $20-40$ & 1.23 & $\begin{array}{l}\text { Broken-line, } \\
\text { exponential }\end{array}$ & 1.11 & 1.14 \\
\hline 152 & $\begin{array}{l}\text { Mack et al } \\
\text { (1999) }\end{array}$ & $\begin{array}{l}0.71,0.80,0.89,0.98,1.07 \\
1.16\end{array}$ & Male & ISA & $20-40$ & 1.22 & $\begin{array}{l}\text { Broken-line, } \\
\text { exponential }\end{array}$ & 1.10 & 1.13 \\
\hline
\end{tabular}




\section{Appendix 6 References omitted in the overall regression of BWG response to AFD and SID lysine content}

\begin{tabular}{|c|c|c|c|c|c|c|c|c|c|c|c|}
\hline \multirow[t]{2}{*}{$\begin{array}{l}\text { Exp } \\
\text { No. }\end{array}$} & \multirow[t]{2}{*}{ Reference } & \multicolumn{2}{|c|}{ Lysine concentration in the diet (\%) } & \multirow[t]{2}{*}{ Gender } & \multirow[t]{2}{*}{ Strain } & \multirow[t]{2}{*}{$\begin{array}{l}\text { Age of } \\
\text { birds }\end{array}$} & \multirow[t]{2}{*}{$\begin{array}{l}\text { Published } \\
\text { Requirement } \\
(\%)\end{array}$} & \multirow[t]{2}{*}{$\begin{array}{l}\text { Models used } \\
\text { by the } \\
\text { reference }\end{array}$} & \multicolumn{2}{|c|}{$\begin{array}{l}\text { Re-calculated requirement for } \\
\text { BWG using exponential } \\
\text { models (lysine content in \% ) }\end{array}$} & \multirow[t]{2}{*}{$\begin{array}{l}\text { Reason for } \\
\text { exclusion* }\end{array}$} \\
\hline & & On AFD basis & On SID basis & & & & & & On AFD basis & On SID basis & \\
\hline 1 & $\begin{array}{l}\text { Garcia et al } \\
(2006)\end{array}$ & $\begin{array}{l}0.7,0.8,0.9,1.0 \\
1.1\end{array}$ & $\begin{array}{l}0.73,0.83,0.93 \\
1.03,1.13\end{array}$ & Male & Cobb & $7-21$ & 0.91 & $\begin{array}{l}\text { Linear and } \\
\text { Quadratic }\end{array}$ & - & - & 2 \\
\hline 23 & $\begin{array}{l}\text { Garcia et al } \\
\text { (2006) }\end{array}$ & $\begin{array}{l}0.7,0.8,0.9,1.0 \\
1.1\end{array}$ & $\begin{array}{l}0.73,0.83,0.93 \\
1.03,1.13\end{array}$ & Female & Cobb & $7-21$ & 0.90 & $\begin{array}{l}\text { Linear and } \\
\text { Quadratic }\end{array}$ & - & - & 2 \\
\hline 24 & $\begin{array}{l}\text { Garcia et al } \\
(2006)\end{array}$ & $\begin{array}{l}0.7,0.8,0.9,1.0 \\
1.1\end{array}$ & $\begin{array}{l}0.73,0.83,0.93 \\
1.03\end{array}$ & Female & Cobb & $7-21$ & 0.82 & $\begin{array}{l}\text { Linear and } \\
\text { Quadratic }\end{array}$ & - & - & 2 \\
\hline 25 & $\begin{array}{l}\text { Garcia et al } \\
(2006)\end{array}$ & $\begin{array}{l}0.80,0.88,0.96 \\
1.04,1.12\end{array}$ & $\begin{array}{l}0.83,0.91,0.99 \\
1.07,1.15\end{array}$ & Male & Cobb & $7-21$ & 1.01 & $\begin{array}{l}\text { Linear and } \\
\text { Quadratic }\end{array}$ & 1.14 & 1.17 & 3 \\
\hline 26 & $\begin{array}{l}\text { Garcia et al } \\
\text { (2006) }\end{array}$ & $\begin{array}{l}0.80,0.88,0.96 \\
1.04,1.12\end{array}$ & $\begin{array}{l}0.83,0.91,0.99 \\
1.07,1.15\end{array}$ & Male & Cobb & $7-21$ & 0.97 & $\begin{array}{l}\text { Linear and } \\
\text { Quadratic }\end{array}$ & 1.10 & 1.13 & 3 \\
\hline 27 & $\begin{array}{l}\text { Garcia et al } \\
\text { (2006) }\end{array}$ & $\begin{array}{l}0.80,0.88,0.96 \\
1.04,1.12\end{array}$ & $\begin{array}{l}0.83,0.91,0.99 \\
1.07,1.15\end{array}$ & Female & Cobb & $7-21$ & 0.97 & $\begin{array}{l}\text { Linear and } \\
\text { Quadratic }\end{array}$ & 1.07 & 1.10 & 3 \\
\hline 210 & $\begin{array}{l}\text { Garcia et al } \\
(2006)\end{array}$ & $\begin{array}{l}0.89,0.97,1.02 \\
1.13,1.21\end{array}$ & $\begin{array}{l}0.92,1.00,1.08 \\
1.16,1.24\end{array}$ & Male & Cobb & $7-21$ & 1.03 & $\begin{array}{l}\text { Linear and } \\
\text { Quadratic }\end{array}$ & 1.15 & 1.18 & 3 \\
\hline 31 & $\begin{array}{l}\text { Dozier et al. } \\
\text { (2009) }\end{array}$ & $\begin{array}{l}0.9,0.97,1.04 \\
1.11,1.18,1.25\end{array}$ & $\begin{array}{l}0.92,0.99,1.06 \\
1.13,1.20,1.27\end{array}$ & male & Ross & $14-28$ & 0.99 & Broken-line & - & - & 2 \\
\hline 42 & $\begin{array}{l}\text { Dozier et al } \\
\text { (2009) }\end{array}$ & $\begin{array}{l}0.85,0.90,0.95 \\
1.00,1.05,1.10 \\
1.15,1.20,1.25\end{array}$ & $\begin{array}{l}0.86,0.91,0.96 \\
1.01,1.06,1.11 \\
1.16,1.21,1.26\end{array}$ & Male & Ross & $14-28$ & 1.15 & Broken-line & 1.42 & 1.43 & 1 \\
\hline 53 & $\begin{array}{l}\text { Dozier \& } \\
\text { Payne (2012) }\end{array}$ & $\begin{array}{l}0.92,1.01,1.08 \\
1.17,1.24,1.29 \\
1.39\end{array}$ & $\begin{array}{l}0.94,1.03,1.10 \\
1.19,1.26,1.31 \\
1.42\end{array}$ & Female & Ross & $1-7$ & 1.38 & $\begin{array}{l}\text { Quadratic } \\
\text { broken line }\end{array}$ & 1.72 & 1.74 & 1 \\
\hline
\end{tabular}




\begin{tabular}{|c|c|c|c|c|c|c|c|c|c|c|c|}
\hline \multirow[t]{2}{*}{$\begin{array}{l}\text { Exp } \\
\text { No. }\end{array}$} & \multirow[t]{2}{*}{ Reference } & \multicolumn{2}{|c|}{ Lysine concentration in the diet (\%) } & \multirow[t]{2}{*}{ Gender } & \multirow[t]{2}{*}{ Strain } & \multirow[t]{2}{*}{$\begin{array}{l}\text { Age of } \\
\text { birds }\end{array}$} & \multirow[t]{2}{*}{$\begin{array}{l}\text { Published } \\
\text { Requirement } \\
(\%)\end{array}$} & \multirow[t]{2}{*}{$\begin{array}{l}\text { Models used } \\
\text { by the } \\
\text { reference }\end{array}$} & \multicolumn{2}{|c|}{$\begin{array}{l}\text { Re-calculated requirement for } \\
\text { BWG using exponential } \\
\text { models (lysine content in \%) }\end{array}$} & \multirow[t]{2}{*}{$\begin{array}{l}\text { Reason for } \\
\text { exclusion* }\end{array}$} \\
\hline & & On AFD basis & On SID basis & & & & & & On AFD basis & On SID basis & \\
\hline 81 & $\begin{array}{l}\text { Mehri et al } \\
(2010)\end{array}$ & $\begin{array}{l}0.62,0.74,0.86 \\
0.98,1.10,1.22\end{array}$ & $\begin{array}{l}0.61,0.73,0.85 \\
0.97,1.09,1.21\end{array}$ & $M+F$ & Ross & $15-28$ & 1.08 & $\begin{array}{l}\text { Linear and } \\
\text { Quadratic } \\
\text { broken line }\end{array}$ & - & - & 2 \\
\hline 121 & $\begin{array}{l}\text { Fatufe et al } \\
(2004)\end{array}$ & $\begin{array}{l}0.31,0.36,0.43 \\
0.60,0.68,0.73 \\
0.93,1.12,1.29 \\
1.53\end{array}$ & $\begin{array}{l}0.32,0.38,0.44 \\
0.61,0.69,0.74 \\
0.94,1.13,1.30 \\
1.54\end{array}$ & Male & Ross & $8-21$ & 0.99 & Logistic models & 3.22 & 3.23 & 1 \\
\hline 131 & $\begin{array}{l}\text { Berri et al } \\
\text { (2008) }\end{array}$ & $\begin{array}{l}0.83,0.93,1.03, \\
1.13\end{array}$ & $\begin{array}{l}0.82,0.92,1.02, \\
1.12\end{array}$ & Male & Ross & $21-42$ & - & $\begin{array}{l}\text { Mean } \\
\text { comparison test }\end{array}$ & - & - & 2 \\
\hline 132 & $\begin{array}{l}\text { Berri et al } \\
\text { (2008) }\end{array}$ & $\begin{array}{l}0.83,0.93,1.03 \\
1.13\end{array}$ & $\begin{array}{l}0.82,0.92,1.02, \\
1.12\end{array}$ & Male & Ross & $21-42$ & - & $\begin{array}{l}\text { Mean } \\
\text { comparison test }\end{array}$ & - & - & 2 \\
\hline
\end{tabular}

* Explanation of codes for exclusion:

$1=$ Calculated requirement $>110 \%$ of highest inclusion level of test amino acid; $2=$ Lack of fit; $3=$ Co-limitation of non-test amino acid(s). 


\section{Appendix 7 References omitted in the overall regression of FCR response to AFD and SID lysine}

\section{content}

\begin{tabular}{|c|c|c|c|c|c|c|c|c|c|c|c|}
\hline \multirow[t]{2}{*}{$\begin{array}{l}\text { Exp } \\
\text { No. }\end{array}$} & \multirow[t]{2}{*}{ Reference } & \multicolumn{2}{|c|}{$\begin{array}{l}\text { Lysine concentration in the diet } \\
(\%)\end{array}$} & \multirow[t]{2}{*}{ Gender } & \multirow[t]{2}{*}{ Strain } & \multirow[t]{2}{*}{$\begin{array}{l}\text { Age of } \\
\text { birds }\end{array}$} & \multirow[t]{2}{*}{$\begin{array}{l}\text { Published } \\
\text { Requirement } \\
(\%)\end{array}$} & \multirow[t]{2}{*}{$\begin{array}{l}\text { Models used } \\
\text { by the } \\
\text { reference }\end{array}$} & \multicolumn{2}{|c|}{$\begin{array}{l}\text { Re-calculated requirement } \\
\text { for FCR using exponential } \\
\text { models (lysine content in \%) }\end{array}$} & \multirow[t]{2}{*}{$\begin{array}{l}\text { Reason for } \\
\text { exclusion* }\end{array}$} \\
\hline & & On AFD basis & On SID basis & & & & & & On AFD basis & On SID basis & \\
\hline 21 & $\begin{array}{l}\text { Garcia et al } \\
\text { (2006) }\end{array}$ & $\begin{array}{l}0.7,0.8,0.9,1.0 \\
1.1\end{array}$ & $\begin{array}{l}0.73,0.83,0.93 \\
1.03,1.13\end{array}$ & Male & Cobb & $7-21$ & 0.96 & $\begin{array}{l}\text { Lineair and } \\
\text { Quadratic }\end{array}$ & - & - & 2 \\
\hline 22 & $\begin{array}{l}\text { Garcia et al } \\
\text { (2006) }\end{array}$ & $\begin{array}{l}0.7,0.8,0.9,1.0, \\
1.1\end{array}$ & $\begin{array}{l}0.73,0.83,0.93 \\
1.03,1.13\end{array}$ & Male & Cobb & $7-21$ & 0.96 & $\begin{array}{l}\text { Lineair and } \\
\text { Quadratic }\end{array}$ & - & - & 2 \\
\hline 23 & $\begin{array}{l}\text { Garcia et al } \\
(2006)\end{array}$ & $\begin{array}{l}0.7,0.8,0.9,1.0, \\
1.1\end{array}$ & $\begin{array}{l}0.73,0.83,0.93 \\
1.03,1.13\end{array}$ & Female & Cobb & $7-21$ & 0.90 & $\begin{array}{l}\text { Linear and } \\
\text { Quadratic }\end{array}$ & - & - & 2 \\
\hline 24 & $\begin{array}{l}\text { Garcia et al } \\
(2006)\end{array}$ & $\begin{array}{l}0.7,0.8,0.9,1.0, \\
1.1\end{array}$ & $\begin{array}{l}0.73,0.83,0.93 \\
1.03\end{array}$ & Female & Cobb & $7-21$ & 0.82 & $\begin{array}{l}\text { Linear and } \\
\text { Quadratic }\end{array}$ & - & - & 2 \\
\hline 25 & $\begin{array}{l}\text { Garcia et al } \\
\text { (2006) }\end{array}$ & $\begin{array}{l}0.80,0.88,0.96 \\
1.04,1.12\end{array}$ & $\begin{array}{l}0.83,0.91,0.99 \\
1.07,1.15\end{array}$ & Male & Cobb & $7-21$ & 1.01 & $\begin{array}{l}\text { Linear and } \\
\text { Quadratic }\end{array}$ & - & - & 2 \\
\hline 26 & $\begin{array}{l}\text { Garcia et al } \\
(2006)\end{array}$ & $\begin{array}{l}0.80,0.88,0.96 \\
1.04,1.12\end{array}$ & $\begin{array}{l}0.83,0.91,0.99 \\
1.07,1.15\end{array}$ & Male & Cobb & $7-21$ & 0.97 & $\begin{array}{l}\text { Linear and } \\
\text { Quadratic }\end{array}$ & - & - & 2 \\
\hline 27 & $\begin{array}{l}\text { Garcia et al } \\
\text { (2006) }\end{array}$ & $\begin{array}{l}0.80,0.88,0.96 \\
1.04,1.12\end{array}$ & $\begin{array}{l}0.83,0.91,0.99 \\
1.07,1.15\end{array}$ & Female & Cobb & $7-21$ & 0.97 & $\begin{array}{l}\text { Linear and } \\
\text { Quadratic }\end{array}$ & - & - & 2 \\
\hline 28 & $\begin{array}{l}\text { Garcia et al } \\
(2006)\end{array}$ & $\begin{array}{l}0.80,0.88,0.96 \\
1.04,1.12\end{array}$ & $\begin{array}{l}0.83,0.91,0.99 \\
1.07,1.15\end{array}$ & Female & Cobb & $7-21$ & 0.97 & $\begin{array}{l}\text { Linear and } \\
\text { Quadratic }\end{array}$ & - & - & 2 \\
\hline 210 & $\begin{array}{l}\text { Garcia et al } \\
(2006)\end{array}$ & $\begin{array}{l}0.89,0.97,1.02 \\
1.13,1.21\end{array}$ & $\begin{array}{l}0.92,1.00,1.08 \\
1.16,1.24\end{array}$ & Male & Cobb & $7-21$ & 1.03 & $\begin{array}{l}\text { Linear and } \\
\text { Quadratic }\end{array}$ & - & - & 2 \\
\hline 212 & $\begin{array}{l}\text { Garcia et al } \\
\text { (2006) }\end{array}$ & $\begin{array}{l}0.89,0.97,1.02 \\
1.13,1.21\end{array}$ & $\begin{array}{l}0.92,1.00,1.08 \\
1.16,1.24\end{array}$ & Female & Cobb & $7-21$ & 1.03 & $\begin{array}{l}\text { Linear and } \\
\text { Quadratic }\end{array}$ & - & - & 2 \\
\hline 31 & $\begin{array}{l}\text { Dozier et al. } \\
\text { (2009) }\end{array}$ & $\begin{array}{l}0.9,0.97,1.04 \\
1.11,1.18,1.25\end{array}$ & $\begin{array}{l}0.92,0.99,1.06 \\
1.13,1.20,1.27\end{array}$ & Male & Ross & $14-28$ & 0.99 & Broken-line & 2.09 & 2.09 & 1 \\
\hline
\end{tabular}




\begin{tabular}{|c|c|c|c|c|c|c|c|c|c|c|c|}
\hline \multirow[t]{2}{*}{$\begin{array}{l}\text { Exp } \\
\text { No. }\end{array}$} & \multirow[t]{2}{*}{ Reference } & \multicolumn{2}{|c|}{$\begin{array}{l}\text { Lysine concentration in the diet } \\
(\%)\end{array}$} & \multirow[t]{2}{*}{ Gender } & \multirow[t]{2}{*}{ Strain } & \multirow[t]{2}{*}{$\begin{array}{l}\text { Age of } \\
\text { birds }\end{array}$} & \multirow[t]{2}{*}{$\begin{array}{l}\text { Published } \\
\text { Requirement } \\
(\%)\end{array}$} & \multirow[t]{2}{*}{$\begin{array}{l}\text { Models used } \\
\text { by the } \\
\text { reference }\end{array}$} & \multicolumn{2}{|c|}{$\begin{array}{l}\text { Re-calculated requirement } \\
\text { for FCR using exponential } \\
\text { models (lysine content in \%) }\end{array}$} & \multirow[t]{2}{*}{$\begin{array}{l}\text { Reason for } \\
\text { exclusion* }\end{array}$} \\
\hline & & On AFD basis & On SID basis & & & & & & On AFD basis & On SID basis & \\
\hline 41 & $\begin{array}{l}\text { Dozier et al } \\
(2009\end{array}$ & $\begin{array}{l}0.85,0.90,0.95 \\
1.00,1.05,1.10 \\
1.15,1.20,1.25\end{array}$ & $\begin{array}{l}0.86,0.91,0.96 \\
1.01,1.06,1.11 \\
1.16,1.21,1.26\end{array}$ & Male & Ross & $14-28$ & 1.15 & Broken-line & 1.35 & 1.36 & 3 \\
\hline 51 & $\begin{array}{l}\text { Dozier \& } \\
\text { Payne (2012) }\end{array}$ & $\begin{array}{l}0.92,1.01,1.08, \\
1.17,1.24,1.29 \\
1.39\end{array}$ & $\begin{array}{l}0.94,1.03,1.10 \\
1.19,1.26,1.31 \\
1.42\end{array}$ & Male & Ross & $7-15$ & 1.38 & $\begin{array}{l}\text { Quadratic } \\
\text { broken line }\end{array}$ & & & 3 \\
\hline 53 & $\begin{array}{l}\text { Dozier \& } \\
\text { Payne (2012) }\end{array}$ & $\begin{array}{l}0.92,1.01,1.08, \\
1.17,1.24,1.29, \\
1.39\end{array}$ & $\begin{array}{l}0.94,1.03,1.10 \\
1.19,1.26,1.31 \\
1.42\end{array}$ & Female & Ross & $1-7$ & 1.38 & $\begin{array}{l}\text { Quadratic } \\
\text { broken line }\end{array}$ & 2.19 & 2.21 & 1 \\
\hline 81 & $\begin{array}{l}\text { Mehri et al } \\
(2010)\end{array}$ & $\begin{array}{l}0.62,0.74,0.86 \\
0.98,1.10,1.22\end{array}$ & $\begin{array}{l}0.61,0.73,0.85 \\
0.97,1.09,1.21\end{array}$ & $M+F$ & Ross & $15-28$ & 1.08 & $\begin{array}{l}\text { Linear and } \\
\text { Quadratic } \\
\text { broken line }\end{array}$ & 3.08 & 3.07 & 1 \\
\hline 121 & $\begin{array}{l}\text { Fatufe et al } \\
(2004)\end{array}$ & $\begin{array}{l}0.31,0.36,0.43, \\
0.60,0.68,0.73, \\
0.93,1.12,1.29, \\
1.53\end{array}$ & $\begin{array}{l}0.32,0.38,0.44 \\
0.61,0.69,0.74 \\
0.94,1.13,1.30 \\
1.54\end{array}$ & Male & Ross & $8-21$ & 0.99 & Logistic models & 1.37 & 1.39 & 3 \\
\hline 131 & $\begin{array}{l}\text { Berri et al } \\
\text { (2008) }\end{array}$ & $\begin{array}{l}0.83,0.93,1.03, \\
1.13\end{array}$ & $\begin{array}{l}0.82,0.92,1.02, \\
1.12\end{array}$ & Male & Ross & $21-42$ & - & $\begin{array}{l}\text { Mean } \\
\text { comparison test }\end{array}$ & - & - & 2 \\
\hline 132 & $\begin{array}{l}\text { Berri et al } \\
\text { (2008) }\end{array}$ & $\begin{array}{l}0.83,0.93,1.03, \\
1.13\end{array}$ & $\begin{array}{l}0.82,0.92,1.02, \\
1.12\end{array}$ & Male & Ross & $21-42$ & - & $\begin{array}{l}\text { Mean } \\
\text { comparison test }\end{array}$ & - & - & 2 \\
\hline 141 & $\begin{array}{l}\text { Dozier et al } \\
(2010)\end{array}$ & $\begin{array}{l}0.64,0.71,0.78 \\
0.85,0.92,0.99 \\
1.06,1.13,1.20\end{array}$ & $\begin{array}{l}0.67,0.74,0.81 \\
0.88,0.95,1.02 \\
1.09,1.16,1.23\end{array}$ & Male & Ross & $28-42$ & 1.05 & $\begin{array}{l}\text { Quadratic } \\
\text { broken line }\end{array}$ & 1.11 & 1.14 & 3 \\
\hline
\end{tabular}

*Explanation of codes for exclusion:

$1=$ Calculated requirement $>110 \%$ of highest inclusion level of test amino acid; $2=$ Lack of fit; $3=$ Co-limitation of non-test amino acid(s). 

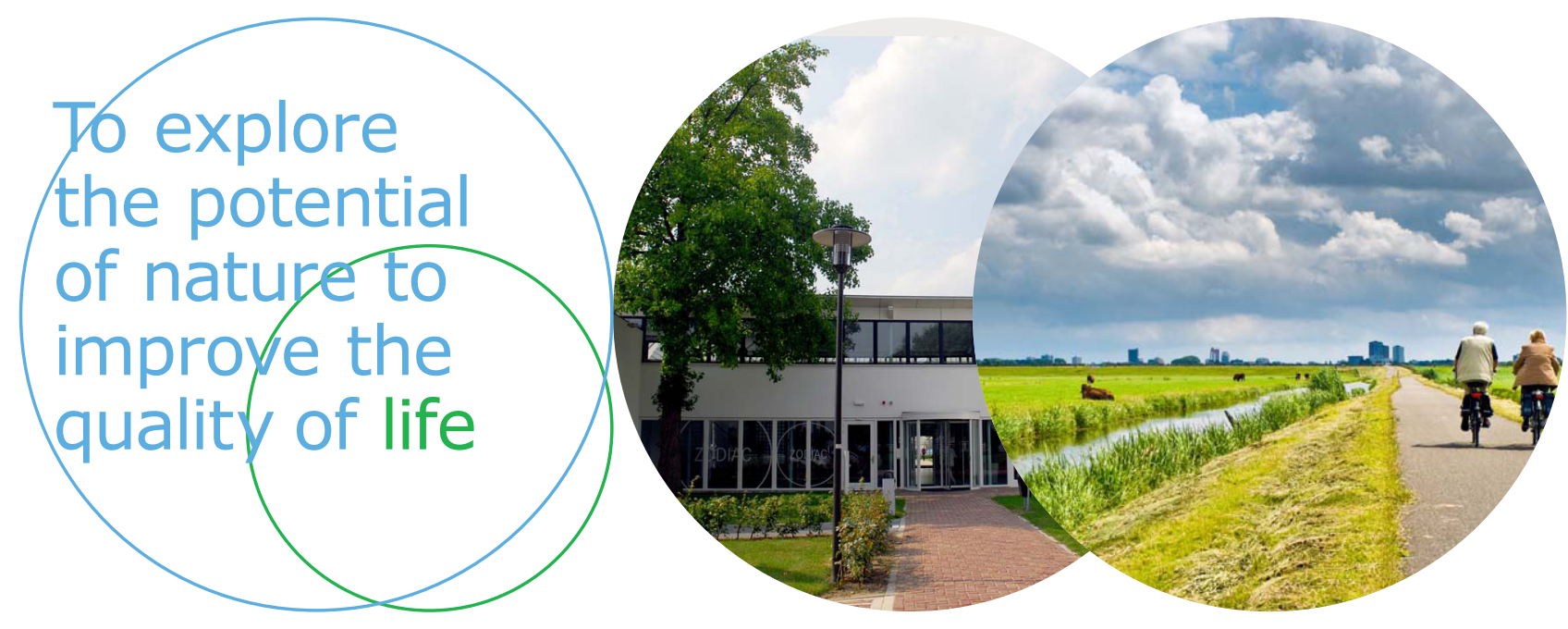

Wageningen UR Livestock Research

P.O. Box 338

$6700 \mathrm{AH}$ Wageningen

The Netherlands

T +31 (0)317483953

E info.livestockresearch@wur.nl

www.wageningenUR.nl/livestockresearch
Together with our clients, we integrate scientific know-how and practical experience to develop livestock concepts for the 21st century. With our expertise on innovative livestock systems, nutrition, welfare, genetics and environmental impact of livestock farming and our state-of-the art research facilities, such as Dairy Campus and Swine Innovation Centre Sterksel, we support our customers to find solutions for current and future challenges.

The mission of Wageningen UR (University \& Research centre) is 'To explore the potential of nature to improve the quality of life'. Within Wageningen UR, nine specialised research institutes of the DLO Foundation have joined forces with Wageningen University to help answer the most important questions in the domain of healthy food and living environment. With approximately 30 locations, 6,000 members of staff and 10,000 students, Wageningen UR is one of the leading organisations in its domain worldwide. The integral approach to problems and the cooperation between the various disciplines are at the heart of the unique Wageningen Approach. 